\title{
EFFECT OF STIRRUPS DENSIFICATION AND REHABILITATION ON BEHAVIOR OF RECTANGULAR (RC) COLUMNS
}

\author{
*Owida, M. E ${ }^{1}$, Elsamny, M. K. ${ }^{2}$, Abd-Elhamed M. K. ${ }^{2}$ and Ezz-Eldeen, H. A. ${ }^{2}$ \\ ${ }^{1}$ Department of Civil Engineering, El Gazeera Higher Institutes for Engineering and \\ Technology, Cairo, Egypt \\ ${ }^{2}$ Department of Civil Engineering, Al- Azhar University, Faculty of Engineering, \\ Cairo, Egypt \\ *Corresponding author E-mail: mahmoudowida@yahoo.com
}

\begin{abstract}
The present study deals with an experimental (EXP) and finite element (FEA) investigation for studying internal confinement during construction by using stirrups densification at top and bottom of columns and the regular stirrups distribution along length of columns with different slenderness ratio $(\lambda)$. Also, it deals with the effect of external confinement for damaged (RC) columns by using steel jacketing technique with a various percentage of covered steel surface area to column surface area $(36,42,50,57$ and 64$)$. A total of twenty reinforced concrete columns specimens having a cross section of $125 \times 250 \mathrm{~mm}$ and a different slenderness $6,8,10$ and 12 have been tested. Columns were divided in two stages; First stage tested four columns to studying internal confinement during construction. It consists of four column specimens with a different slenderness ratio $6,8,10$ and 12 tested. The results in first stage; give a decrease in the load carrying by increasing the slenderness ratio.
\end{abstract}

The increase in internal stirrups volumetric ratio by using densification of stirrups along of column resulted in higher ultimate load. The failure of columns caused due to spall off concrete after stirrups densification zone, thus signifying the large stress concentration after densification directly. Second stage tested twenty columns until failure to study the internal and external confinement for damaged (RC) columns. All damaged concrete parts were removed and replaced the loose concrete part with grout mortar and retrofitted by using steel straps jacketing technique. The steel jacket consists of four vertical steel angles placed at each corner of column and connected together with horizontal steel straps. The results in second stage; gives an increases in the column carrying capacity by increasing percentage of covered steel surface area to column surface area and decrease by increasing slenderness ratio.

The optimum percentages of covered steel surface area to column surface area are $25,28,32$ and $36 \%$ for different slenderness ratio $6,8,10$ and 12 for the rehabilitation of damaged (RC) columns so that the column reaches the original. Faire agreement was found between finite element (FEA) results and experimental (EXP) results. However, the (FEA) models can identify the structure behavior of tested columns and can be excellent alternative of destructive laboratory test.

KEYWORDS : (RC) Columns; Capacity; Axially Loaded; Slenderness Ratio; Stirrups; Densification; Rehabilitation; Failure Load; Straps; Experimental (EXP); Finite Element (FEA) 

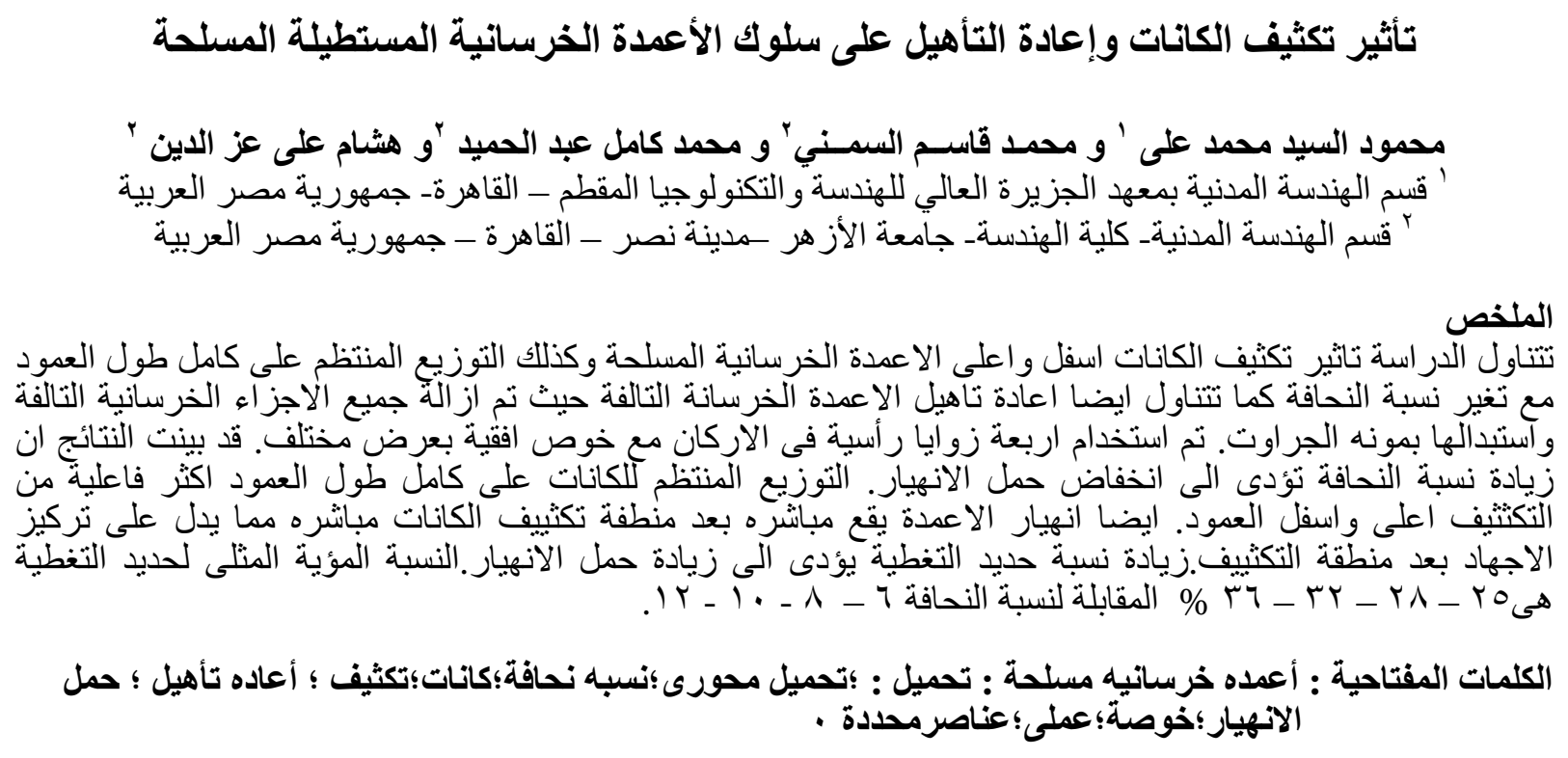

\section{INTRODUCTION}

The most critical structure elements used to resist several loads in the building which play a significant role are the columns. Numbers of reinforced concrete columns may be damaged by earthquakes or due to the deficiencies in the design. The columns can deteriorate for several reasons such as the evolution and changing habits of the loads. In addition, the columns during construction may be subjected to several problems. When those problems occur, the columns exhibit damage and the columns cannot reach their ultimate load carrying capacity. Therefore, rehabilitation of columns is necessary. Engineers have used different methods and techniques to strengthen columns by providing internal confining stresses during construction and external confining stresses after construction.

Internal confinement means that the internal configuration of transverse reinforcement should be made in a way to increase the lateral resistance of reinforced concrete columns and consequently increasing the ultimate compressive capacity of column. Many researchers investigated the internal confinement of reinforced concrete columns. Only a few studies involved the effect of stirrups densification at top and bottom of (RC) columns and regular densification along of (RC) columns with different slenderness ratio.

External confinement means that the external configuration of steel detailing combined with new concrete jacket or configuration of techniques of steel jacket are used to enhance the performance of original reinforcement concrete members. When the RC columns are subjected to large deformation due to seismic motion, the ability to resist the acting loads will be based on the internal confinement while the column core is weak and can't resist such deformation, additional external confinement should be applied. Many researchers investigated the strengthening of reinforced concrete columns. Only a few studies involved rehabilitation of damaged reinforced concrete columns. So, the purpose of the present study is investigated the effect of stirrups densification at top and bottom of (RC) columns and regular densification along of (RC) columns as well as rehabilitation damaged reinforced concrete columns with different slenderness ratio

Etman, E. (2010) ${ }^{[1]}$ presented an experimental program consisted of twenty seven specimens to investigate the behavior of reinforced concrete (RC) columns with slenderness ratio $(\lambda=20)$ for the un-braced rectangular columns under the effect of eccentric loads. The program contained three groups each have 9 specimens. The first group was considered as a control group tested without confinement and the second group was confined by using near surface mounted (NSM) longitudinal steel bars while the third group was confined by using NSM longitudinal steel bars partially wrapped with one ply of carbon fibers reinforced polymers (CFRP) sheets. In addition to the strengthening schemes, the test parameters included the investigation on the change in the ratio of the internal longitudinal steel bars as well as the 
stirrups' volumetric ratio. All specimens were tested by eccentric loading with eccentricity-to section height e/h equals 0.25 . The results shown that the strengthening columns for third group showed better improvement in load capacity at the same value of lateral buckling than columns strengthened by second group. Increasing the longitudinal internal reinforcement for the strengthened columns did not show the same increase in ultimate load as in reference columns.

Soliman, A. E. K. S. (2011) ${ }^{[2]}$ investigated the behavior of long concrete columns confined by means of proper plastic tube including failure mechanisms with theoretical model for calculation of the column capacity. The influence of column slenderness ratio on their axial load capacity, axial strains, and radial strains were also investigated. The experimental program was classified into three different groups with slenderness ratios from 9 to 18 . Test results showed that, utilizing plastic tube for confinement significantly influences the failure mechanisms of concrete columns. Results also showed that the stiffness of the tested long confined concrete columns specimens increases as slenderness ratio decreases.

Malhotra, et al. (2013) ${ }^{[3]}$ investigated (R.C) columns with three different slenderness ratios 3,7 and 15 . These specimens were further divided in to three categories. First category consisted of three unconfined control columns from each size group, second category consisted of three column confined with ferrocement using one layer of wire mesh and third category consisted of three columns confined with ferrocement using two layers of wire mesh. All the columns were tested under monotonic uniaxial compression loading. The results showed that ferrocement confinement increases the load carrying capacity and decreases the lateral deflection. The increase in slenderness ratio results in a decrease of strength of the ferrocement confinement.

Hales, T. A., et al. (2016) ${ }^{[4]}$ studied the behavior of slender high-strength concrete columns reinforced with glass fiber-reinforced polymer (GFRP) bars and spirals subjected to concentric and eccentric axial loads. Large-scale tests were conducted for nine circular concrete columns (three short and six slender) reinforced with internal GFRP-spirals and either steel, GFRP, or a combination of steel and GFRP longitudinal bars. The short and slender columns have slenderness ratios equal to 10 and 49, respectively. Axial load tests were conducted with loads placed concentrically (short columns) and at two eccentricities (slender columns) to observe the general behavior associated with different geometric and loading conditions. The behavior of slender columns with small eccentricity ( $8.3 \%$ of the column size) was governed by material failure, while that of slender columns with large eccentricity (33\% of column size) was governed by a buckling failure. The research shows that GFRP spirals and GFRP longitudinal bars are a viable method of reinforcement for slender concrete columns subjected to eccentric axial loads.

Sheikh, T. R., et al. (2017) ${ }^{[5]}$ investigated the confinement of (RC) short square columns with ferrocement jacketing. A total of six RC short square columns were casted and three of them were taken as control specimens. The specimens were tested to failure after 28 days under pure axial concentric loading in order to investigate the effect of strengthening with ferrocement jacket as an alternative technique to classical RC Jacketing. The observed experimental ultimate axial load carrying capacity of retrofitted columns was compared with the calculated theoretical values. Moreover, the effect of jacketing on the slenderness ratio of column was also studied and initial cracking load as well as ultimate load carrying capacity were recorded and discussed for future scope. From the result analysis, it was observed that the retrofitted column showed an increase of $62 \%$ in the ultimate load carrying capacity.

The objective of the presented study is to determine the effect of stirrups densification and rehabilitation on behavior of rectangular (RC) columns as follows:-

i. Studying the effect of internal confinement by using stirrups densification at top and bottom of columns and the regular distribution along length of columns with different slenderness ratio.

ii. Studying the effect of external confinement by using steel jacketing technique with various percentage of covered steel surface area to column surface area on the behavior of damaged ( $\mathrm{RC}$ ) columns.

iii. Determination of optimum percentages of covered steel surface area to column surface area to rehabilitation damaged (RC) columns. 
iv. Obtain of failure modes before and after rehabilitation of damage columns for (RC) columns.

v. Presenting finite element model to simulate the studying the effect of internal confinement by using stirrups densification at top and bottom of columns as well as the regular stirrups distribution along of columns.

vi. $\quad$ Presenting finite element model to simulate studying effect of external confinement by using steel jacketing technique with various percentage of covered steel surface area to column surface area on the behavior of damaged (RC) columns.

\section{EXPERIMENTAL PROGRAM}

A total of twenty reinforced concrete column specimens having a cross section of $125 \mathrm{x}$ $250 \mathrm{~mm}$ and a different slenderness 6,8,10 and 12.All columns contained six longitudinal reinforcement normal mild steel bars $8 \mathrm{~mm}$ diameter and stirrups $6 \mathrm{~mm}$ diameter bars. The longitudinal reinforcement was $8 \mathrm{~mm}$ diameter with yield strength $280 \mathrm{MPa}$, providing a steel content of $1 \%$ of the cross section.

\subsection{COLUMNS CHARACTERISTICS}

\subsubsection{USED MATERIALS}

i. Fine aggregates having sizes in the range of $(0.075-0.3 \mathrm{~mm})$ was used as a fine aggregate in the mix.

ii. Crushed stone has a maximum nominal size of $(0.07-20.0 \mathrm{~mm})$ was used as a coarse aggregate in the mix.

iii. Ordinary Portland cement obtained from Siena factory was used in all the experimental work. The usual chemical and physical properties are in compliance with the Egyptian Standard Specification (BS EN) 197-1/2011.

iv. Clean fresh water is used for mixing and curing the specimens. Percentage of water cement ratio $50 \%$.

v. Normal mild steel bars St24/37 of diameter 8.0 and $6 \mathrm{~mm}$ were used.

vi. The concrete mix used in all specimens was designed according to the Egyptian code of practice. The concrete mix was designed to obtain target strength of $20 \mathrm{MPa}$ at the age of 28 days. The mix proportions of the concrete are shown in Table [1].

vii. Using cementations mix (Cetorex grout mortar) that needs only the addition of water achieving a high strength non-shrink mortar.

viii. The steel angles used in rehabilitation have a yield stress of $325 \mathrm{MPa}$ and tensile strength of $420 \mathrm{MPa}$.

ix. Kemapoxy 165 an adhesive mortar is pre-filled medium viscosity and solvent free. It contains two components product on the basis of modified epoxy resin giving an appropriate hardening system.

\subsection{INTERNAL CONFINEMENT BY USING DENSIFICATION OF STIRRUPS DURING CONSTRUCTION}

The work carried out has been planned to investigate effect of internal confinement by using stirrups densification at top and bottom of columns with different slenderness ratio as shown in Table [2]. Details of group-1 as follows:-

Group -1:- Consists of four column specimens with a different slenderness ratio 6, 8, 10 and 12 tested under axial load which have a different percentage of stirrups densification height to total column height $[\Delta / \mathrm{H}]$ are $33,25,20$, and $17 \%$ and the stirrups volumetric ratio $[\rho \mathrm{t} \%$ ] are $0.93,0.82,0.76$ and $0.72 \%$ respectively as shown in Figure [1] and Figure [2].The spacing between stirrups in densification zone is $41.67 \mathrm{~mm}$, While the spacing between stirrups in out of densification zone is $125 \mathrm{~mm}$ according to code limits (The maximum vertical spacing for stirrups is $15 x$ the smallest longitudinal bar diameter or width of column but not more than 200 $\mathrm{mm}$ ). The minimum stirrups volumetric ratio is $0.25 \%$ according to ECP 203.

\subsection{STRAIN GAUGES}

Strain Gauges have been mounted inside all specimens on the two longitudinal reinforcement bars and two strain gauges were also mounted externally on the rehabilitated columns. The location of strain gauges mounted inside and outside all specimens as follows:- 


\subsubsection{INTERNAL STRAIN}

Two strain gauges have been located at the mid height on the longitudinal reinforcement bars. One of these gauges was firmly fixed on the vertical corner steel bar (Strain I); while the other was firmly fixed on the middle vertical steel bar (Strain II).

\subsubsection{EXTERNAL STRAIN}

One of these gauges was firmly fixed at the second steel strap from column top (Strain III); while the other was mounted on the fourth steel strap from column top (strain IV).

The strain gauges used were manufactured by TOKYO SOKKI KENKYUJO CO. LYD. The used type named PFL-30-11-3L, which has a resistance of $120.4 \pm 0.5 \mathrm{nd} \% \mathrm{Ohms}$ at $11^{\circ} \mathrm{C}$, and a gauge factor of $2.13 \pm 1.0 \%$. Figure (3) the location of strain gauges.

\subsection{CASTING AND CURING OF COLOUMNS}

The tested columns were casted in wooden forms and a mechanical vibrator was used. Figure [4] shows the wooden forms. Columns forms were removed and columns specimens were cured. Figure [5] and Figure [6] show casting and curing columns respectively.

\subsection{TESTING SETUP AND PROCEDURE}

\subsubsection{TESTING SETUP}

All column specimens were tested under static axially loads at the material laboratory of AlAzhar University. Loading frame was manufactured to resist the expected maximum load. The loading frame and test setup is shown in Figure [7].All columns were tested until failure after 28 days from casting.

\subsubsection{LOAD JACK, LOAD CELL AND DATA ACQUISITION SYSTEM}

The testing load was applied using hydraulic jack with manual pump as shown in Figure [7]. Data acquisition system connected to load cell consisted of a computer and the lab tech notebook software.

\subsection{EXTERNAL CONFINEMENT FOR DAMAGED (RC) COLUMNS}

All columns were tested until damage after 28 days from casting then rehabilitated it to reach to original before damage. The rehabilitation was carried out in two phases; local and general rehabilitation.

\subsubsection{LOCAL REHABILITATION TECHNIQUE FOR DAMAGED COLUMNS}

For damaged concrete areas, loose concrete is removed and the surface is roughened and dust is removed. Temporary cast form is constructed. After one day, the form can be removed and fresh concrete can be chipped away. Figure [8] shows a localized removal and replacement of a damaged part of a concrete column.

\subsubsection{REMOVAL OF DAMAGE CONCRETE AREAS}

Damaged concrete areas and loose concrete were removed, the surface is roughened and dust is removed as shows in Figure [9].

\subsubsection{REPLACEMENT OF DAMAGE CONCRETE AREAS BY CASTING GROUT MORTAR}

The damaged columns were placed in their own forms then the surface of the old concrete are painted by adhesive material to ensure adhesion of the concrete surface of the old concrete with grout mortar as shows in Figure [10]. CETOREX grout mortar with high-strength, non-shrink was used for replacing the damaged concrete part and restore specimens dimension.

\subsubsection{GENERAL REHABILITATION TECHNIQUE FOR DAMAGED COLUMNS}

Steel jacketing technique used for rehabilitation damaged (RC) column by using four external vertical steel angles $(25 \times 25 \times 3) \mathrm{mm}$ connected with horizontal steel straps. Figure [11] shows general rehabilitation technique for damaged columns.

\subsubsection{FIXING OF VERTICAL STEEL ANGLE}

A non-shrinkable material (KEMAPOXY 165) was used to fix the vertical steel angle in corner of columns as shown in Figure [12].

\subsubsection{WRAPING THE HORIZONTALSTRAPS AND FIXATION BY WELDEDINTHE}

$$
\text { VERTICALANGLES }
$$

The horizontal straps were wrapped on the column. Straps and angles were fixed by welding as shown in Figure [13].

\subsubsection{FIXING OF HORIZONTAL STEEL STRAPS}

Figure [14] shows applying epoxy adhesive mortar to ensure full contact between straps and surface of concrete columns. 
The experimental program for external confinement for damaged (RC) columns is shown in Table [3] contains of four groups as following:-

Group -1R:-Consists of five column specimens with a same slenderness ratio 6 tested under axial load which have a percentage of stirrups densification height to total column height $[\Delta / \mathrm{H}=33 \%]$ and the stirrups volumetric ratio $\left[\rho_{\mathrm{t}} \%=0.93 \%\right]$. Also it was rehabilitated by using four external vertical steel angles $(25 \times 25 \times 3) \mathrm{mm}$ connected with horizontal steel 7 straps with a variable width $20,30,40,50$ and $60 \mathrm{~mm}$ [percentage of covered steel surface area to column surface area 36,42,50,57 and 64\%] welded to the angles as shown in Figure [15] as example.

Group -2R:-Consists of five column specimens with a same slenderness ratio 8 tested under axial load which have a percentage of stirrups densification height to total column height $[\Delta / \mathrm{H}=25 \%]$ and the stirrups volumetric ratio $\left[\rho_{\mathrm{t}} \%\right](0.82 \%)$. Also it was rehabilitated by using four external vertical steel angles $(25 \times 25 \times 3) \mathrm{mm}$ connected with horizontal steel 9 straps with a variable width $20,30,40,50$ and $60 \mathrm{~mm}$ [percentage of covered steel surface area to column surface area 36,42,50,57 and 64\%] welded to the angles.

Group -3R:-Consists of five column specimens with a same slenderness ratio10 tested under axial load which have a percentage of stirrups densification height to total column height $[\Delta / \mathrm{H}$ $=20 \%]$ and the stirrups volumetric ratio $\left[\rho_{t} \%\right](0.76 \%)$.Also it was rehabilitated by using four external vertical steel angles $(25 \times 25 \times 3) \mathrm{mm}$ connected with horizontal steel 11 straps with a variable width $20,30,40,50$ and $60 \mathrm{~mm}$ [percentage of covered steel surface area to column surface area $36,42,50,57$ and $64 \%$ ] welded to the angles.

Group -4R:-Consists of five column specimens with a same slenderness ratio12 tested under axial load which have a percentage of stirrups densification height to total column height $[\Delta / \mathrm{H}$ $=17 \%$ ] and the stirrups volumetric ratio $\left[\rho_{\mathrm{t}} \%\right](0.72 \%)$. Also it was rehabilitated by using four external vertical steel angles $(25 \times 25 \times 3) \mathrm{mm}$ connected with horizontal steel 13 straps with a variable width 20,30,40,50 and $60 \mathrm{~mm}$ [percentage of covered steel surface area to column surface area $36,42,50,57$ and $64 \%$ ] welded to the angles.

Figure [16] shows details of rehabilitated damage (RC) columns with a different slenderness ratio $(6,8,10$ and 12$)$ and percentage of covered steel surface area to column surface area $36 \%$ as example.

\section{EXPERIMENTAL TEST RESULTS \\ 3.1. EXPERIMENTAL TEST RESULTS FOR INTERNAL CONFINEMENT FOR(RC) DURING CONSTRUCTION}

Table [2] shows the ultimate loads obtained from (EXP) results for columns with internal confinement.

\subsubsection{ULTIMATE LOADS}

Figure [17] shows the effect of slenderness ratio on the ultimate loads for columns with internal confinement by using densification of stirrups during construction $[\Delta / \mathrm{H}](33,25,20$, and $17 \%$ ).

From Figure [17], it can be shown that the use of internal confinement by using densification of stirrups during construction gives a decrease in the load carrying by increasing the slenderness.

\subsubsection{MODES OF FAILURE}

For group-1 with internal confinement by using densification of stirrups at top + bottom of columns as increasing load inclined cracks started to appear on surface of column. The cracks increased with the increasing load the column. The concrete cover spall off and a visible buckling of longitudinal reinforcement with outside buckling in the stirrups occurred from one side. When the load reached failure load, crushing was observed and total collapse of specimens occurred as shown in Figure [18].It was found from Figure [18] that the failure of columns caused due to spall off concrete after the stirrups densification zone. 


\subsection{EXPERIMENTAL TEST RESULTS FOR EXTERNAL CONFINEMENT FOR DAMAGED (RC) COLUMNS}

Table [3] shows the ultimate loads obtained from (EXP) results for columns with external confinement.

\subsubsection{ULTIMATE LOADS}

Figure [19] shows the relationship between slenderness ratio $(\lambda)$ and ultimate load with different percentage of covered steel surface area to column surface area $\left(A_{S S}\right) 36,42,50,57$ and $64 \%$ and control columns. It can be shown from Figure [19] that the used internal and external confinement by using densification of stirrups and different parentage of covered steel surface area to column surface area gives a decrease in the load carrying by increasing the slenderness. Figure [20] shows the relationship between slenderness ratio $(\lambda)$ and percentage of columns carrying capacity with different percentage of covered steel surface area to column surface area (Ass) 36,42,50,57 and $64 \%$ and control columns. It can be shown from Figure [20] that the column carrying capacity decreases by increasing the slenderness ratio.

Figure [21] shows the relationship between percentage of column carrying capacity and percentage of covered steel surface area to column surface area for columns with a different slenderness ratio 6,8,10 and 12. It can be shown from Figure [21] that the column carrying capacity increases by increasing percentage of covered steel surface area to column surface area for damaged (RC) columns.

\subsubsection{LOAD AND STRAIN IN INTERNAL REINFORCEMENT AND EXTERNAL STEEL STRAPS}

Figure [22] shows the relationship between load and strain at corner and middle steel bars for vertical internal reinforcement as well as strain at second and fourth steel straps for group -1R with slenderness ratio $(\lambda=6)$ and percentage of covered steel surface area to column surface area $\left(\mathrm{A}_{\mathrm{SS}}=36 \%\right)$ for example . Table (3) shows load and recorded strain at external steel straps. It was found that the recorded strain increases by increasing percentage of covered steel surface area to column surface area and ductility increase.

\subsubsection{MODES OF FAILURE}

Figure [23] shows modes of failure for rehabilitated columns. It was found that the failure occurred in the top third of the column height. The position of failure is after to the second strap.

\section{FINITE ELEMENT ANALYSIS}

The finite element package ANSYS 15.0 was used in order to simulate the obtained experimental testing by introducing a numerical model. The tested columns in the experimental work were modeled to determine the failure loads and strains to simulate the effect internal confinement by using densification of stirrups and external confinement by using four external vertical steel angles connected with horizontal steel straps (Steel jacketing technique).

\subsection{STAGES OF FINITE ELEMENT MODEL}

There are five main stages to model columns specimen:-

i. Defining element types, real constants, and material properties.

ii. Modeling the geometry of column specimens.

iii. Meshing the specimen geometry.

iv. Applying boundary conditions and loads on specimen.

v. Loading procedure and analysis of the results.

\subsubsection{MODEL OF CONCRETE}

The concrete is modeled using hexahedral elements (SOLID 65) type with eight corner nodes having three translation degrees of freedom at each node. The Young's modulus for concrete was taken $19677 \mathrm{MPa}$ and Poisson's ratio was taken to be (0.2). The stress- strain curve was defined for concrete element in "ANSYS" program with $\mathrm{f}_{\mathrm{cu}}=20 \mathrm{MPa}$ as shown in Figure [24]. Figure [25] shows concrete elements.

\subsubsection{MODEL OF LONGITUDINAL AND TRANSVERSE REINFORCEMENT} STEEL ELEMENTS

The longitudinal and transverse steel is modeled using LINK180 element type. Both yielding and strain-hardening failure modes can be accounted. The yield stress, $F_{y}=280 \mathrm{MPa}$. The Young's modulus for reinforcement was taken $2.0 \times 10^{5} \mathrm{MPa}$ and Poisson's ratio was taken to 
be (0.3). The idealized stress-strain curve for the internal vertical and horizontal reinforcement was used in the finite element model as shown in [26]. Figure [27] shows create longitudinal and transverse reinforcement elements.

\subsubsection{MODEL OF LOADING PLATE}

The loading plate is modeled using (SOLID 45) element type. This element is defined by eight nodes which three degrees of freedom. The Young's modulus for internal steel was taken $2.0 \times 10^{5} \mathrm{MPa}$ and Poisson's ratio was assumed to be (0.3).

\subsubsection{MODEL OF STEEL JACKET [ANGLES AND STRAPS]}

The proposed rehabilitation technique consists of four vertical steel angles connected together by using with horizontal steel straps with different dimension. The steel jacket is modeled using quadrilateral shell elements SHELL181, with four nodes each of six degree of freedom of yield stress, $F_{y}=325$ MPa. The Young's modulus for reinforcement was taken $2.0 \times 10^{5} \mathrm{MPa}$ and Poisson's ratio was taken to be (0.3). Figure [28] shows the modeling of steel jacket.

\subsubsection{APPLYING BOUNDARY CONDITIONS AND LOADS ON SPECIMEN}

Boundary conditions were applied accordingly to simulate the experimental conditions at the base joints of specimen in horizontal translations and rotations in three directions as shown in Figure [29].

\section{COMPARISON BETWEEN EXPERIMENTAL AND ANALYTICAL FINITE ELEMENTS RESULTS}

\subsection{ULTIMATE LOADS}

Table [4] shows comparison between ultimate loads obtained from (EXP) and (FEA) analysis for (RC) columns with internal confinement during construction.

Table [5] shows comparison between ultimate loads obtained from (EXP) and (FEA) analysis for (RC) columns with external confinement for damaged (RC) columns.

Figure [30] shows comparison between slenderness ratio $(\lambda)$ and ultimate load obtained from (FEA) and (EXP) results for columns with internal confinement by using different percentage of stirrups densification $(\Delta / \mathrm{h}) 33,25,20$ and $17 \%$ and different slenderness ratio $(\lambda) 6,8,10$ and 12 respectively. Figure [31] shows comparison between slenderness ratio $(\lambda)$ and ultimate load obtained from (FEA) and (EXP) results for external confinement for damaged (RC) columns with different slenderness ratio $(\lambda)$ $6,8,10$ and 12 and percentage of covered steel surface area to column surface area $\left(\mathrm{A}_{\mathrm{SS}}\right) 36 \%$.

Figure [32] shows comparison between slenderness ratio $(\lambda)$ and percentage of column carrying capacity obtained from (FEA) and (EXP) results external confinement for damaged (RC) columns with different slenderness ratio $(\lambda) 6,8,10$ and 12 and percentage of covered steel surface area to column surface area $\left(\mathrm{A}_{\mathrm{sS}}\right) 36 \%$.

Figure [33] shows comparison between percentage of columns carrying capacity and percentage of covered steel area to column surface area $\left(\mathrm{A}_{\mathrm{SS}}\right)$ obtained from (FEA) and (EXP) results external confinement for damaged (RC) columns.

The obtained results showed Faire agreement between finite element (FEA) results and experimental (EXP) results and the results obtained from (FEA) is greater than results obtained from (EXP).

\subsection{MODES OF FAILURE}

Figures [34 to 37] show comparison between modes of failure obtained from (FEA) and (EXP) model for columns with internal confinement by using stirrups densification at top and bottom of columns $[\Delta / \mathrm{H}] 33 \%, 25.20 .17$ reactively. From the figures; it has been seen generally that, the failure of columns are due to spall off concrete between stirrups densification zones, thus signifying large stress concentration after densification directly. Faire agreement is obtained between finite element (FEA) results and experimental (EXP) results.

Figure [38] show comparison between modes of failure obtained from (EXP.) and (FEA) for rehabilitated columns by 4 angles $25 \times 3$ and straps $60 \times 3 \mathrm{~mm}$. It can be shown from Figure [38] that the obtained failure modes from (EXP) have the same shape of (FEA). From figure; it has been noticed that the failure for rehabilitated columns occurred in the top third of the column height. $I$

\section{PARAMETRIC STUDY AND ANALYTICAL RESULTS TO STUDY EFFECT OF STIRRUPS DENSIFICATION}

As illustrated in previous, finite element models performed with numerical analysis using ANSYS15.0 predict truly the analysis and discussion of the effect of stirrups densification and rehabilitation of reinforced concrete columns. Thus, it is possible to perform a parametric study with numerical finite element model followed by indications as illustrated previously. Table [6] shows parametric study by using (FEA) for regular stirrups distribution. 
Figure [39] shows concrete dimension and reinforcement for group -2 consists of four columns with a different slenderness ratio $(\lambda=6,8,10$ and 12) and regular stirrups distribution each $41.67 \mathrm{~mm}$ as well as stirrups volumetric ratio equal $1.58 \%$.The spacing between stirrups according to code limits (The maximum vertical spacing for stirrups is $15 x$ the smallest longitudinal bar diameter or width of column but not more than $200 \mathrm{~mm}$ ). The minimum stirrups volumetric ratio is $0.25 \%$ according to ECP 203.

Figure [40] shows comparison between slenderness ratio $(\lambda)$ and ultimate load obtained from (FEA) results for columns with internal confinement by using stirrups densification at top and bottom of columns and regular stirrups distribution. It can be shown from Figure [40] that the effect of the slenderness ratio on the load carrying capacity of columns with internal confinement by using distribution of stirrups along of column during construction is more significant than that of columns with internal confinement by using densification of stirrups at top + bottom of columns.

Finite element models performed with numerical analysis using ANSYS15.0 predict truly the analysis and discussion of the optimum percentage of covered steel surface area to column surface area .Figure [41] shows the relationship between slenderness ratio $(\lambda)$ and the optimum percentage of covered steel surface area to column surface area $\left(\mathrm{A}_{\mathrm{ss}}\right)$ for rehabilitated columns. It can be shown from Figure [41] that the optimum percentages of covered steel surface area to column surface area are 25, 28, 32 and $36 \%$ for different slenderness ratio $6,8,10$ and 12 respectively for the rehabilitation of damaged (RC) columns so that the column reaches the original.

\section{CONCLUSIONS}

From the present study, the following conclusions are obtained:-

i. The increase in internal stirrups volumetric ratio by using densification of stirrups along of column during construction resulted in higher ultimate load.

ii. The failures of columns are due to spall off concrete between stirrups densification zones, thus signifying the large stress concentration after densification directly.

iii. Steel jacketing technique proved to be an easy, inexpensive in rehabilitation of damaged (RC) columns.

iv. The column carrying capacity increases by increasing percentage of covered steel surface area to column surface area and decreases by increasing slenderness ratio.

v. The optimum percentages of covered steel surface area to column surface area are $25,28,32$ and $36 \%$ for columns with different slenderness ratio $6,8,10$ and 12 for the rehabilitation of damaged (RC) columns so that the column reaches the original.

vi. Faire agreement was found between finite element (FEA) results and experimental (EXP) results. However, the (FEA) models can identify the structure behavior of tested columns and can be excellent alternative of destructive laboratory test.

\section{REFERENCES}

1. Etman, E. (2010). Experimental Study on The Behavior of Slender Rectangular Columns Under Eccentric Loading. Concrete Research Letters, 1(2), 45-59.

2. Soliman, A. E. K. S. (2011). Behavior of long confined concrete column. Ain Shams Engineering Journal, 2(3-4), 141-148.

3. Malhotra, J., Bansal, P. G. (2013), "Behavior of RCC columns confined with ferrocement". Journal of Composites for Construction Vol.17, Issus 4, PP. 443-453.

4. Hales, T. A., Pantelides, C. P., \& Reaveley, L. D. (2016). Experimental evaluation of slender high-strength concrete columns with GFRP and hybrid reinforcement. Journal of Composites for Construction, 20(6), 04016050.

5. Sheikh, T. R., Khan, M. K. and Izhar, T. (2017), "Strengthening of RC short square columns subjected to concentric axial loading by Ferrocement Jacketing". International Research Journal of Engineering and Technology (IRJET) Vol. 4 ,Issue4, PP. 3490-3495.

Table [1] Concrete mix design

\begin{tabular}{|c|c|}
\hline Constituents & Mixproportions by weightform \\
\hline Crushed stone & $1108 \mathrm{Kg}$ \\
\hline Gradatesand & $640 \mathrm{Kg}$ \\
\hline Water & $135 \mathrm{Liter}$ \\
\hline Cement & $270 \mathrm{Kg}$ \\
\hline Watercementratio(w/c) & $50 \%$ \\
\hline
\end{tabular}


Table [2] Internal confinement during construction for (RC) columns

\begin{tabular}{|c|c|c|c|c|c|c|c|c|c|c|c|c|c|}
\hline \multirow{2}{*}{$\frac{6}{3}$} & \multirow{2}{*}{$\frac{\underbrace{}_{0}}{8}$} & \multirow{2}{*}{$\begin{array}{c}\text { Simups } \\
\text { dstribtion } \\
\text { method }\end{array}$} & \multicolumn{3}{|c|}{$\begin{array}{c}\text { Cohmms dimension; } \\
\text { (mm) }\end{array}$} & \multirow{2}{*}{ 焉 } & \multirow{2}{*}{$\begin{array}{c}\text { Heightofsimus } \\
\text { densificationmesattop+ } \\
\text { bottomofoumms; } \\
\text { mm[L] }\end{array}$} & \multirow{2}{*}{ 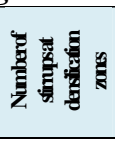 } & \multirow{2}{*}{$\begin{array}{c}\text { TodalNaof } \\
\text { simus }\end{array}$} & \multirow{2}{*}{$\begin{array}{c}\text { Simups } \\
\text { vilumtric } \\
\text { ratio\% \% } \\
{\left[\rho_{\mathrm{d}}\right]}\end{array}$} & \multirow{2}{*}{$\begin{array}{c}\text { \%ofstimus } \\
\text { densicationattop+ } \\
\text { bottomofodhms; } \% \\
\text { (MH) }\end{array}$} & \multirow{2}{*}{$\begin{array}{c}\text { Longsted } \\
\text { ratiox }[\mu]\end{array}$} & \multirow{2}{*}{$\begin{array}{c}\text { Ulimate } \\
\text { hads(EXP) } \\
\text { (KN) }\end{array}$} \\
\hline & & & b & $\mathbf{t}$ & $\mathbf{h}$ & & & & & & & & \\
\hline \multirow{4}{*}{ 할 } & C11 & \multirow{4}{*}{$\begin{array}{c}\text { simus } \\
\text { densificationattop } \\
\text { +bottomof } \\
\text { ahmms }\end{array}$} & \multirow{4}{*}{125} & \multirow{4}{*}{250} & 750 & 6 & \multirow{4}{*}{250} & \multirow{4}{*}{8} & 11 & $093 \%$ & $\mathbf{3 3} \%$ & \multirow{4}{*}{$1 \%$} & 660 \\
\hline & $\mathrm{C12}$ & & & & 1000 & 8 & & & $\mathbf{1 3}$ & $082 \%$ & $25 \%$ & & 26 \\
\hline & $\mathbf{C B}$ & & & & 1250 & 10 & & & 15 & $076 \%$ & $20 \%$ & & 614 \\
\hline & C14 & & & & 1500 & 12 & & & 17 & $0.72 \%$ & $17 \%$ & & 600 \\
\hline
\end{tabular}

Table [3] External confinement for damaged (RC) columns

\begin{tabular}{|c|c|c|c|c|c|c|c|c|c|c|c|c|c|c|c|c|c|c|c|}
\hline \multirow[b]{2}{*}{ हैं } & \multirow[b]{2}{*}{ है } & \multirow{2}{*}{ 吾案 } & \multicolumn{3}{|c|}{$\underset{(\mathrm{mm})}{\operatorname{Calmmsdmanim;}}$} & \multirow{2}{*}{ 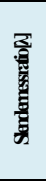 } & \multirow[b]{2}{*}{$\begin{array}{c}{[\Delta]} \\
\mathbf{~ m m}\end{array}$} & \multirow{2}{*}{ 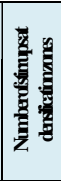 } & \multirow{2}{*}{ है } & \multirow{2}{*}{ 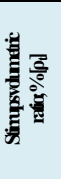 } & \multirow[b]{2}{*}{$\stackrel{(\mathrm{MH})}{\%}$} & \multicolumn{2}{|c|}{ Jadkt } & \multirow[b]{2}{*}{$\stackrel{(\text { Ass) }}{\%}$} & \multicolumn{2}{|c|}{$\begin{array}{l}\text { Ulimatehadfimm(EXP) } \\
\text { (KN) }\end{array}$} & \multirow[b]{2}{*}{$\begin{array}{c}\text { ohmn } \\
\text { canjig } \\
\text { cepary } \\
\%\end{array}$} & \multicolumn{2}{|c|}{ Strainindedstraps $(\%)$} \\
\hline & & & b & $\mathbf{t}$ & h & & & & & & & $\begin{array}{l}\text { Veticidted } \\
\text { angles }\end{array}$ & Hoinntidtedtraps & & $\begin{array}{c}\text { Intemal } \\
\text { anfineme } \\
\text { it } \\
\text { (Contril) }\end{array}$ & $\begin{array}{l}\text { Intemaland } \\
\text { evemal } \\
\text { Coffinemet }\end{array}$ & & $\begin{array}{c}\text { atseand } \\
\text { stedtsrap } \\
\text { fium } \\
\text { odimntop } \\
\text { (III) }\end{array}$ & $\begin{array}{c}\text { atfiumh } \\
\text { stedtrap } \\
\text { firm } \\
\text { ochmmtop } \\
\text { (IV) }\end{array}$ \\
\hline \multirow{5}{*}{ 을 } & C11R & \multirow{5}{*}{ 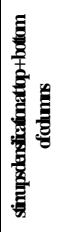 } & \multirow{5}{*}{125} & \multirow{5}{*}{280} & \multirow{5}{*}{ 75) } & \multirow{5}{*}{6} & \multirow{5}{*}{280} & \multirow{5}{*}{8} & \multirow{5}{*}{11} & \multirow{5}{*}{$093 \%$} & \multirow{5}{*}{$33 \%$} & \multirow{5}{*}{$\begin{array}{c}\mathbf{4}(\mathbf{2} \times \mathbf{3}) \\
\mathbf{m m}\end{array}$} & 7.fraps $20 \times 3 \mathbf{m m}$ & $36 \%$ & \multirow{5}{*}{660} & 940 & $14 \%$ & $0.129 \%$ & $002 \%$ \\
\hline & CER & & & & & & & & & & & & 7firaps30k3mm & $\mathfrak{4} \%$ & & 1020) & $100 \%$ & $00185 \%$ & $0027 \%$ \\
\hline & C13R & & & & & & & & & & & & 7.fraps $40 \times 3 \mathrm{~mm}$ & $\mathbf{5 0 \%}$ & & 1039 & $15 \%$ & $0000 \%$ & $0080 \%$ \\
\hline & C14R & & & & & & & & & & & & 7fraps $51 \times 32 m$ & $5 \%$ & & 1061 & $161 \%$ & $0048 \%$ & $0013 \%$ \\
\hline & C1ER & & & & & & & & & & & & 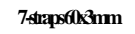 & $64 \%$ & & 1097 & $166 \%$ & $004 \%$ & $005 \%$ \\
\hline & C2IR & $\Xi$ & & & & & & & & & & & 9draps $201 \times 3 \mathrm{~mm}$ & $36 \%$ & & 820 & $\mathbf{B 1} \%$ & $0008 \%$ & $0021 \%$ \\
\hline & $\mathrm{C} 2 \mathrm{R}$ & 㽦 & & & & & & & & & & & 9draps30k3m & $\mathcal{4} \%$ & & 815 & $135 \%$ & $00134 \%$ & $0025 \%$ \\
\hline है & C23R & है & 125 & 280 & 1000 & 8 & 280 & 8 & 13 & $082 \%$ & $25 \%$ & $\begin{array}{l}\mathbf{4}(2 \times 3 \times 3) \\
\mathbf{m m}\end{array}$ & 9draps $40 \times 2 \times m$ & $\mathbf{5 0} \%$ & 26 & 867 & $139 \%$ & $0009 \%$ & $0029 \%$ \\
\hline & C2AR & 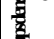 & & & & & & & & & & & 9draps $51 \times 3 \mathrm{~mm}$ & $5 \%$ & & 879 & $140 \%$ & $005 \%$ & $00122 \%$ \\
\hline & C2SR & 真 & & & & & & & & & & & 9drapsolo $3 \mathrm{~mm}$ & $64 \%$ & & 85 & $143 \%$ & $000 \%$ & $00188 \%$ \\
\hline & C3IR & $\Xi$ & & & & & & & & & & & 11-draps $20 \times 3 \mathrm{~mm}$ & $36 \%$ & & $\theta 1$ & $113 \%$ & $0028 \%$ & $0019 \%$ \\
\hline & C $22 R$ & 高。 & & & & & & & & & & & 11-frap3033mm & $\mathfrak{4} \%$ & & 711 & $116 \%$ & $0080 \%$ & $0023 \%$ \\
\hline है & C33R & $\frac{3}{8}$ & 125 & 250 & 1280 & 10 & 280 & 8 & 15 & $076 \%$ & $20 \%$ & $\begin{array}{c}4(2 \times 3) \\
\mathrm{mm}\end{array}$ & 11-strap $40 \times 1 \times 3 m$ & $\mathbf{5 0 \%}$ & 64 & 745 & $121 \%$ & $00186 \%$ & $0027 \%$ \\
\hline & C34R & $\frac{5}{8}$ & & & & & & & & & & & 11-fraps $50 \mathbf{k} 3 \mathbf{m m}$ & $5 \%$ & & 781 & $127 \%$ & $0041 \%$ & $0080 \%$ \\
\hline & C3FR & & & & & & & & & & & & 11-drap 50 : $3 \mathrm{~mm}$ & $64 \%$ & & 800 & $130 \%$ & $004 \%$ & $0086 \%$ \\
\hline & C4IIR & $\mathrm{E}$ & & & & & & & & & & & 13 draps $20103 \mathrm{~mm}$ & $36 \%$ & & 616 & $103 \%$ & $002 \%$ & $0017 \%$ \\
\hline$\approx$ & CAER & 季 & & & & & & & & & & & 13drap $30 \times 3 m m$ & $\mathcal{4} \%$ & & 26 & $105 \%$ & $\mathbf{0 0 3 0} \%$ & $0021 \%$ \\
\hline 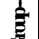 & CABR & $\frac{5}{8}$ & 125 & 280 & 1500 & 12 & 280 & 8 & 17 & $072 \%$ & $17 \%$ & $\begin{array}{l}4(2 \times 3) \\
\mathbf{m m}\end{array}$ & 13 draps $40 \times 3 \mathrm{~mm}$ & $\mathbf{5 0 \%}$ & 600 & 646 & $108 \%$ & $00185 \%$ & $0026 \%$ \\
\hline & C4AR & 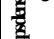 & & & & & & & & & & & 13draps $91 \times 3 \mathrm{~mm}$ & $57 \%$ & & 683 & $114 \%$ & $0041 \%$ & $0029 \%$ \\
\hline & CAR & & & & & & & & & & & & 13 drap 50 : $3 \mathrm{~mm}$ & $64 \%$ & & 700 & $117 \%$ & $004 \%$ & $0012 \%$ \\
\hline
\end{tabular}

R: : Rehabilitated columns.

$\Delta: \quad$ : Height of stirrups densification zones at top + bottom of columns; $\mathrm{mm}[\Delta]$

$(\Delta / \mathrm{H})$ : Parentage of stirrups densification at top + bottom of columns; \%

$\mathrm{A}_{\mathrm{ss}}$ : : Parentage of covered steel surface area to column surface area

Table [4] Comparison between ultimate loads obtained from experimental and finite element analysis for (RC) columns with internal confinement during construction

\begin{tabular}{|c|c|c|c|c|c|c|c|c|c|c|c|c|c|c|}
\hline \multirow{2}{*}{$\stackrel{气}{0}$} & \multirow{2}{*}{ 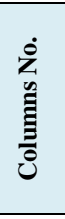 } & \multirow{2}{*}{$\begin{array}{c}\text { Stirrups } \\
\text { distribution } \\
\text { method }\end{array}$} & \multicolumn{3}{|c|}{$\begin{array}{l}\text { Columns } \\
\text { dimension; } \\
(\mathrm{mm})\end{array}$} & \multirow{2}{*}{ 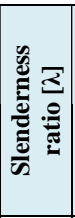 } & \multirow{2}{*}{$\begin{array}{c}\text { Heightof } \\
\text { simups } \\
\text { densification } \\
\text { zonesattop } \\
\text { +bottomof } \\
\text { columm; } \\
\text { mm }[\Delta]\end{array}$} & \multirow{2}{*}{ 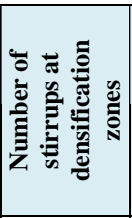 } & \multirow{2}{*}{$\begin{array}{c}\text { Total } \\
\text { No. of } \\
\text { stirrups }\end{array}$} & \multirow{2}{*}{$\begin{array}{c}\text { Stirrups } \\
\text { volumetric } \\
\text { ratio; \% } \\
{\left[\rho_{\mathrm{t}}\right]}\end{array}$} & \multirow{2}{*}{$\begin{array}{c}\% \text { of stirrups } \\
\text { densification at } \\
\text { top + bottom of } \\
\text { columns; } \% \\
(\Delta / H)\end{array}$} & \multirow{2}{*}{$\begin{array}{l}\text { Long. } \\
\text { steel } \\
\text { ratio; } \\
{[\mu]}\end{array}$} & \multicolumn{2}{|c|}{$\begin{array}{l}\text { Ultimate loads } \\
(\mathrm{KN})\end{array}$} \\
\hline & & & b & $\mathbf{t}$ & h & & & & & & & & (EXP) & (FEA) \\
\hline \multirow{4}{*}{ 厄) } & C 11 & \multirow{4}{*}{$\begin{array}{c}\text { stirrups } \\
\text { densification } \\
\text { at top + } \\
\text { bottom of } \\
\text { columns }\end{array}$} & \multirow{4}{*}{125} & \multirow{4}{*}{250} & 750 & 6 & \multirow{4}{*}{250} & \multirow{4}{*}{8} & 11 & $0.93 \%$ & $33 \%$ & \multirow{4}{*}{$1 \%$} & 660 & 665 \\
\hline & C 12 & & & & 1000 & 8 & & & 13 & $0.82 \%$ & $25 \%$ & & 626 & 629 \\
\hline & C 13 & & & & 1250 & 10 & & & 15 & $0.76 \%$ & $20 \%$ & & 614 & 620 \\
\hline & C 14 & & & & 1500 & 12 & & & 17 & $0.72 \%$ & $17 \%$ & & 600 & 603 \\
\hline
\end{tabular}


EFFECT OF STIRRUPS DENSIFICATION AND REHABILITATION ON BEHAVIOR OF RECTANGULAR (RC) COLUMNS

Table [5] Comparison between ultimate loads obtained from experimental and finite element analysis for (RC) columns

\begin{tabular}{|c|c|c|c|c|c|c|c|c|c|c|c|c|c|c|c|c|c|c|}
\hline 을 & $\frac{z}{8}$ & 量 & \multicolumn{3}{|c|}{$\begin{array}{l}\text { Columis dimensian; } \\
\text { (mm) }\end{array}$} & 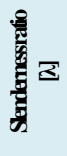 & $\begin{array}{c}{[\Delta]} \\
\mathbf{m m}\end{array}$ & 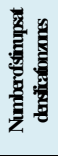 & 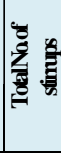 & 象惫 & $\stackrel{(\mathrm{MH})}{\%}$ & \multicolumn{2}{|r|}{ Jadket } & $\begin{array}{l}\text { (Ass) } \\
\%\end{array}$ & \multicolumn{2}{|c|}{$\begin{array}{l}\text { Ulimateloadsform } \\
\text { (KN) }\end{array}$} & \multicolumn{2}{|c|}{$\begin{array}{c}\text { columncaryingcapaity } \\
\%\end{array}$} \\
\hline \multirow{5}{*}{ 光 } & Cl1R & \multirow{5}{*}{ 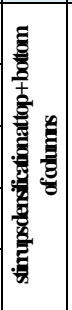 } & \multirow{5}{*}{125} & \multirow{5}{*}{250} & \multirow{5}{*}{750} & \multirow{5}{*}{6} & \multirow{5}{*}{250} & \multirow{5}{*}{8} & \multirow{5}{*}{11} & \multirow{5}{*}{$093 \%$} & \multirow{5}{*}{$33 \%$} & \multirow{5}{*}{$\begin{array}{c}4 \mathrm{~L}(25 \times 3) \\
\mathrm{mm}\end{array}$} & 7-straps $20 \times 3 \mathrm{~mm}$ & $\begin{array}{l}36 \\
\%\end{array}$ & 940 & 986 & $142 \%$ & $148 \%$ \\
\hline & CDR & & & & & & & & & & & & 7-straps30x3mm & $\begin{array}{l}42 \\
\%\end{array}$ & 1020 & 1084 & $100 \%$ & $163 \%$ \\
\hline & C1BR & & & & & & & & & & & & 7-straps40x3mm & $\begin{array}{l}\mathbf{5 0} \\
\% \\
\end{array}$ & 1039 & 1117 & $157 \%$ & $168 \%$ \\
\hline & C14R & & & & & & & & & & & & 7-straps50x3mm & $\begin{array}{l}57 \\
\%\end{array}$ & 1061 & 1139 & $161 \%$ & $171 \%$ \\
\hline & ClsR & & & & & & & & & & & & 7-straps $60 \times 3 \mathrm{~mm}$ & $\begin{array}{l}64 \\
\% \\
\end{array}$ & 1097 & 1162 & $166 \%$ & $175 \%$ \\
\hline \multirow{5}{*}{ 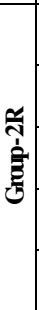 } & C2IR & \multirow{5}{*}{ 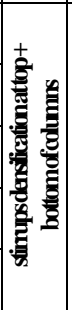 } & \multirow{5}{*}{125} & & & & & & & & & & 9-straps $20 \times 3 \mathrm{~mm}$ & $\begin{array}{l}36 \\
\% \\
\end{array}$ & 820 & 836 & $131 \%$ & $133 \%$ \\
\hline & $\mathrm{C} 2 \mathrm{R}$ & & & & & & & & & & & & 9-straps30x3mm & $\begin{array}{l}2 \\
\% \\
\end{array}$ & 845 & 861 & $135 \%$ & $137 \%$ \\
\hline & C23R & & & 250 & 1000 & 8 & 250 & 8 & 13 & $082 \%$ & $25 \%$ & $\begin{array}{c}4 \mathbf{L}(25 \mathrm{x}) \\
\mathbf{m m}\end{array}$ & 9-straps $40 \times 3 \mathrm{~mm}$ & $\begin{array}{l}\mathbf{5 0} \\
\%\end{array}$ & 867 & 887 & $139 \%$ & $141 \%$ \\
\hline & C2AR & & & & & & & & & & & & 9straps50x3mm & $\begin{array}{l}57 \\
\% \\
\end{array}$ & 879 & 914 & $140 \%$ & $145 \%$ \\
\hline & $\mathrm{C} 2 \mathrm{R}$ & & & & & & & & & & & & 9-straps60x3mm & $\begin{array}{l}64 \\
\%\end{array}$ & 895 & 941 & $143 \%$ & $150 \%$ \\
\hline & C3IR & & & & & & & & & & & & 11-straps $20 \times 3 \mathrm{~mm}$ & $\begin{array}{l}36 \\
\%\end{array}$ & 61 & 714 & $113 \%$ & $115 \%$ \\
\hline$\simeq$ & $\mathrm{C}$ Z2R & है & & & & & & & & & & & 11-straps30x3mm & $\begin{array}{l}42 \\
\%\end{array}$ & 711 & 743 & $116 \%$ & $120 \%$ \\
\hline है: & C33R & 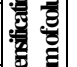 & 125 & 250 & 1250 & 10 & 250 & 8 & 15 & $0.76 \%$ & $20 \%$ & $\begin{array}{c}4 \mathbf{L}(25 \mathrm{x}) \\
\mathbf{m m}\end{array}$ & 11-straps $40 \times 3 \mathrm{~mm}$ & $\begin{array}{l}\mathbf{5 0} \\
\%\end{array}$ & 745 & 788 & $121 \%$ & $127 \%$ \\
\hline & C3AR & 密 & & & & & & & & & & & 11-straps50x3mm & $\begin{array}{l}57 \\
\%\end{array}$ & 781 & 803 & $127 \%$ & $130 \%$ \\
\hline & C.3RR & & & & & & & & & & & & 11-straps60x3mm & $\begin{array}{l}64 \\
\% \\
\end{array}$ & 800 & $\mathbf{8 4}$ & $130 \%$ & $136 \%$ \\
\hline & C4IR & & & & & & & & & & & & 13-straps $20 \times 3 \mathrm{~mm}$ & $\begin{array}{l}36 \\
\% \\
\end{array}$ & 616 & 631 & $103 \%$ & $105 \%$ \\
\hline है & C43R & $\mid \begin{array}{ll}0 \\
0\end{array}$ & 125 & 250 & 1500 & 12 & 250 & 8 & 17 & $0.72 \%$ & $17 \%$ & $\begin{array}{c}\mathbf{4 L}(25 \mathrm{x}) \\
\mathrm{mm}\end{array}$ & 13-straps $40 \times 3 \mathrm{~mm}$ & $\begin{array}{l}\mathbf{5 0} \\
\%\end{array}$ & 646 & 682 & $108 \%$ & $113 \%$ \\
\hline 5 & $\mathbf{C} \mathbb{4 R}$ & 을 & & & & & & & & & & & 13-straps50x3mm & $\begin{array}{l}57 \\
\%\end{array}$ & 683 & $\mathbf{7 0 3}$ & $114 \%$ & $117 \%$ \\
\hline & CAR & & & & & & & & & & & & 13 straps $60 \times 3 \mathrm{~mm}$ & $\begin{array}{l}64 \\
\%\end{array}$ & 700 & 731 & $117 \%$ & $121 \%$ \\
\hline
\end{tabular}

R: : Rehabilitated columns.

$\Delta: \quad$ : Height of stirrups densification zones at top + bottom of columns; $\mathrm{mm}[\Delta]$

$(\Delta / \mathrm{H})$ : Parentage of stirrups densification at top + bottom of columns; \%

L : Equal steel angle

$\mathrm{A}_{\mathrm{ss}}$ : : Parentage of covered steel surface area to column surface area

Table [6] Parametric study by using (FEA) for internal confinement during construction for (RC) columns

\begin{tabular}{|c|c|c|c|c|c|c|c|c|c|c|c|}
\hline$\stackrel{0}{3}$ & 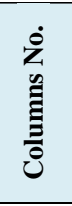 & $\begin{array}{c}\text { Stirrups } \\
\text { distribution } \\
\text { method }\end{array}$ & \multicolumn{3}{|c|}{$\begin{array}{l}\text { Columns } \\
\text { dimension; } \\
(\mathbf{m m})\end{array}$} & 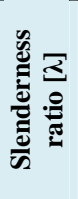 & $\begin{array}{c}\text { Total } \\
\text { No. of } \\
\text { stirrups }\end{array}$ & $\begin{array}{c}\text { Stirrups } \\
\text { volumetric } \\
\text { ratio; \% } \\
{\left[\rho_{\mathrm{t}}\right]}\end{array}$ & $\begin{array}{c}\% \text { of stirrups } \\
\text { densification at } \\
\text { top + bottom of } \\
\text { columns; \% } \\
(\Delta / \mathrm{H})\end{array}$ & $\begin{array}{l}\text { Long. } \\
\text { steel } \\
\text { ratio; } \\
{[\mu]}\end{array}$ & $\begin{array}{l}\text { Ultimate } \\
\text { loads } \\
\text { (KN) } \\
\text { (FEA) }\end{array}$ \\
\hline \multirow{3}{*}{ 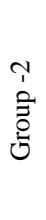 } & C 21 & \multirow{3}{*}{$\begin{array}{c}\text { Regular } \\
\text { distribution @ } \\
41 \mathrm{~mm} \\
(\Delta / \mathrm{H}=100 \%)\end{array}$} & \multirow{3}{*}{125} & \multirow{3}{*}{250} & 750 & 6 & 19 & \multirow{3}{*}{$1.58 \%$} & \multirow{3}{*}{$100 \%$} & \multirow{3}{*}{$1 \%$} & 805 \\
\hline & C 23 & & & & 1250 & 10 & 31 & & & & 749 \\
\hline & C 24 & & & & 1500 & 12 & 37 & & & & 715 \\
\hline
\end{tabular}


EFFECT OF STIRRUPS DENSIFICATION AND REHABILITATION ON BEHAVIOR OF RECTANGULAR (RC) COLUMNS

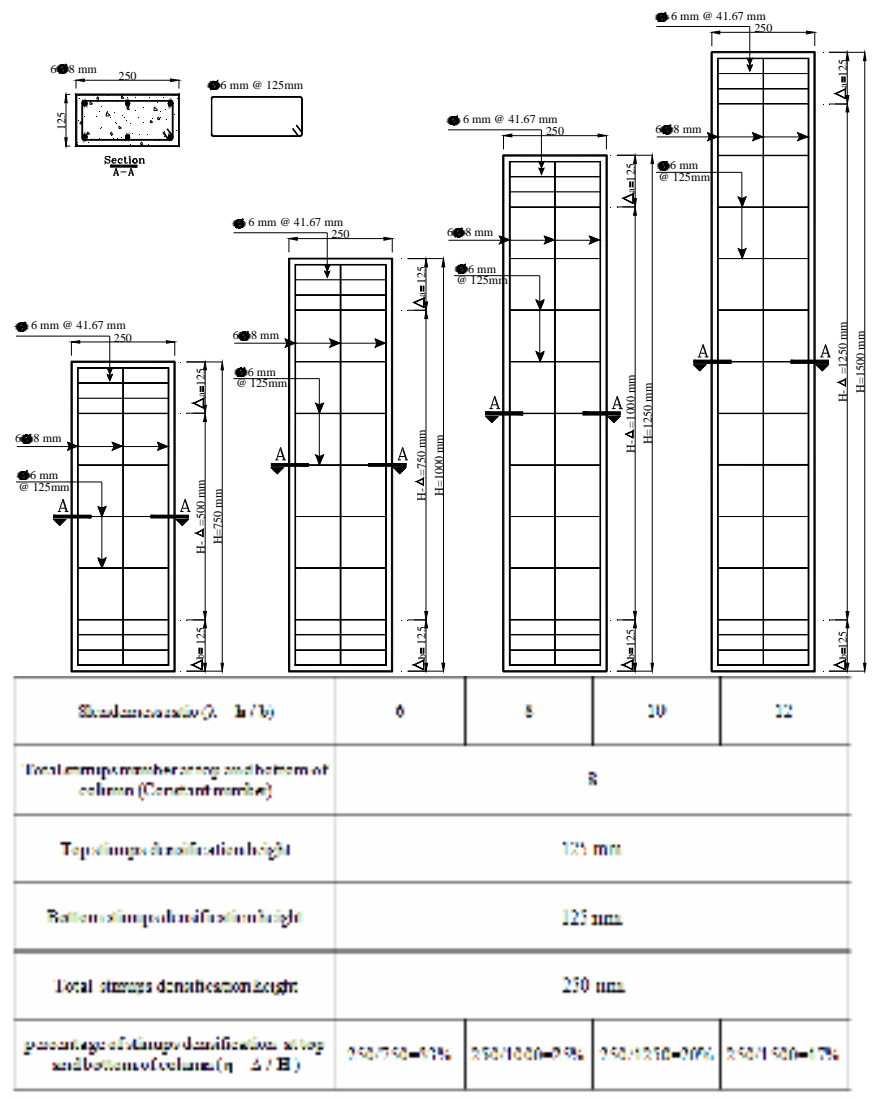

Figure[1] Concretedimension and stimups densification details for group - 1 with different percentage of stimups densification $(\Delta \mathrm{h}) 33,25,20$ and $17 \%$ and different slendemess ratio (入) 6,8,10and 12 respectively

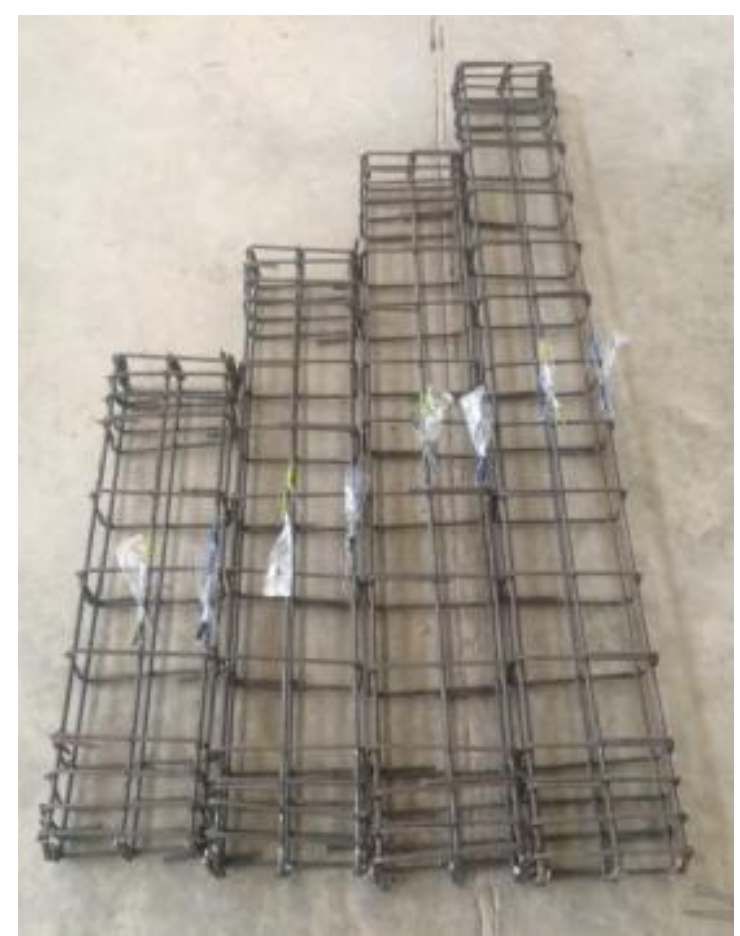

Figure[2]Reinforcement for group-1 with differentpercentage of stimups densification $(\Delta h) 33,25,20$ and $17 \%$ and different slendemess ratio $(\lambda) 6,8,10$ and 12 respectively

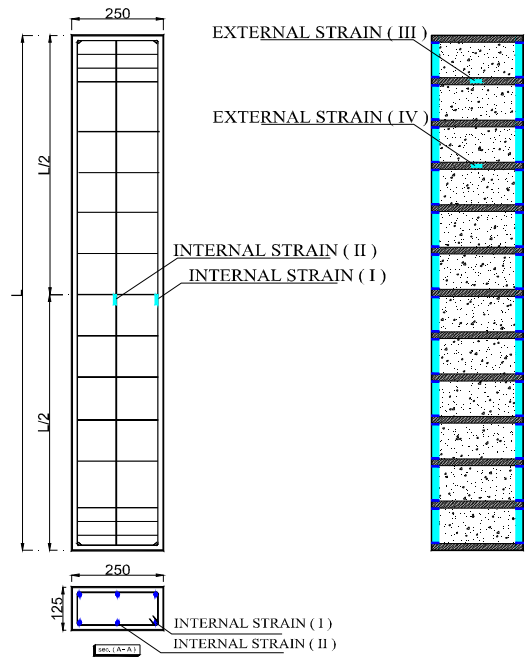

Figure[3] Location of strain gauges

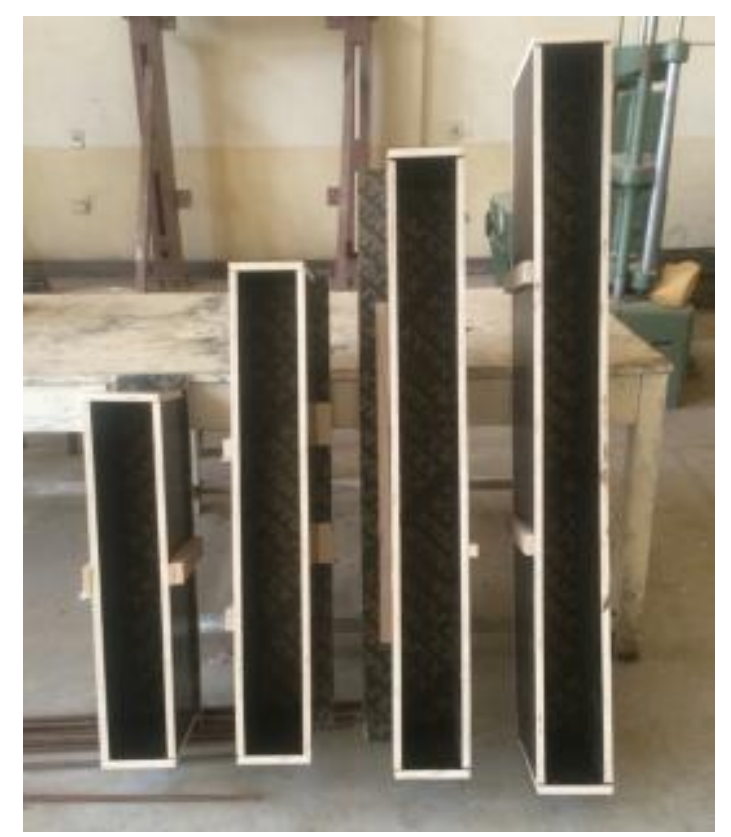

Figure[4]Woodenforms forcolumnscasting

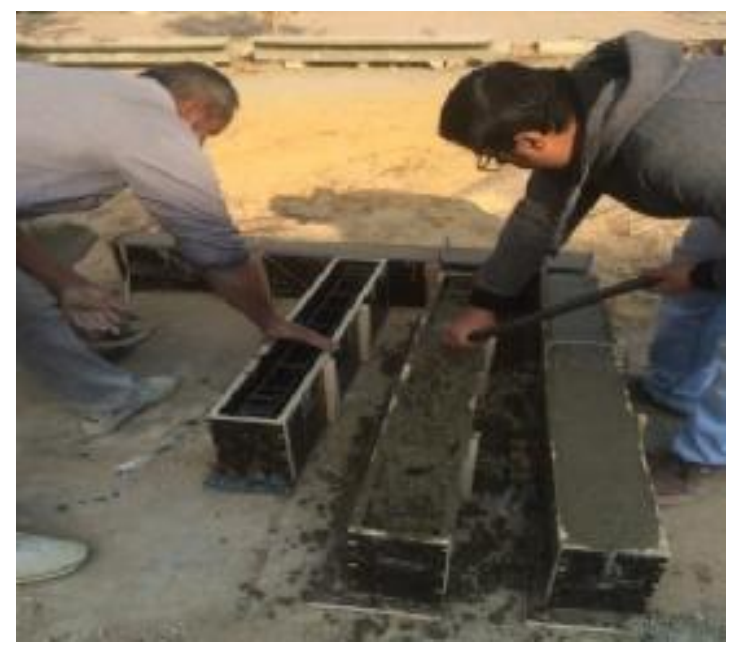

Figure[5]Columnscasting 
EFFECT OF STIRRUPS DENSIFICATION AND REHABILITATION ON BEHAVIOR OF RECTANGULAR (RC) COLUMNS

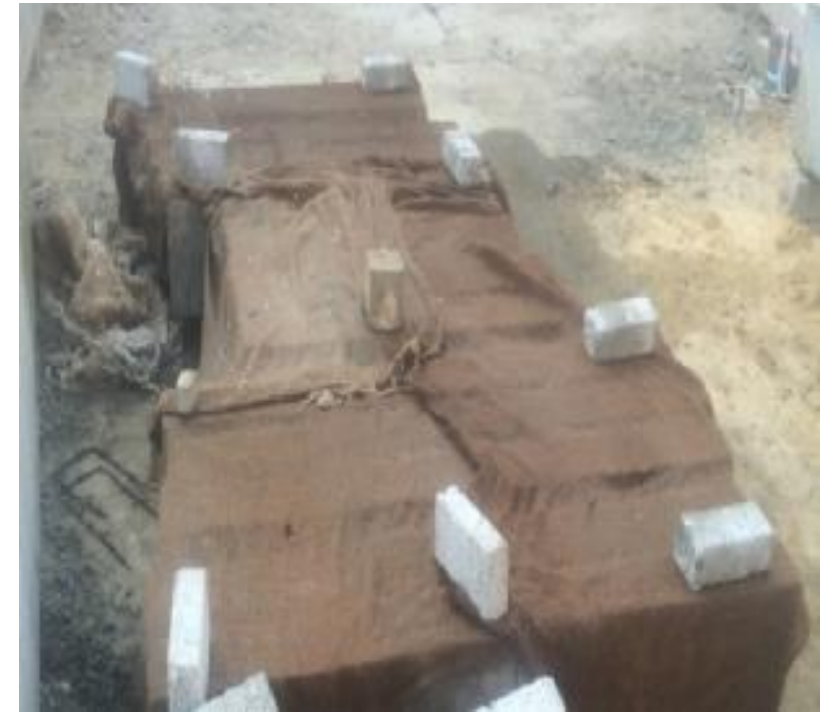

Figure[6]Columns curing

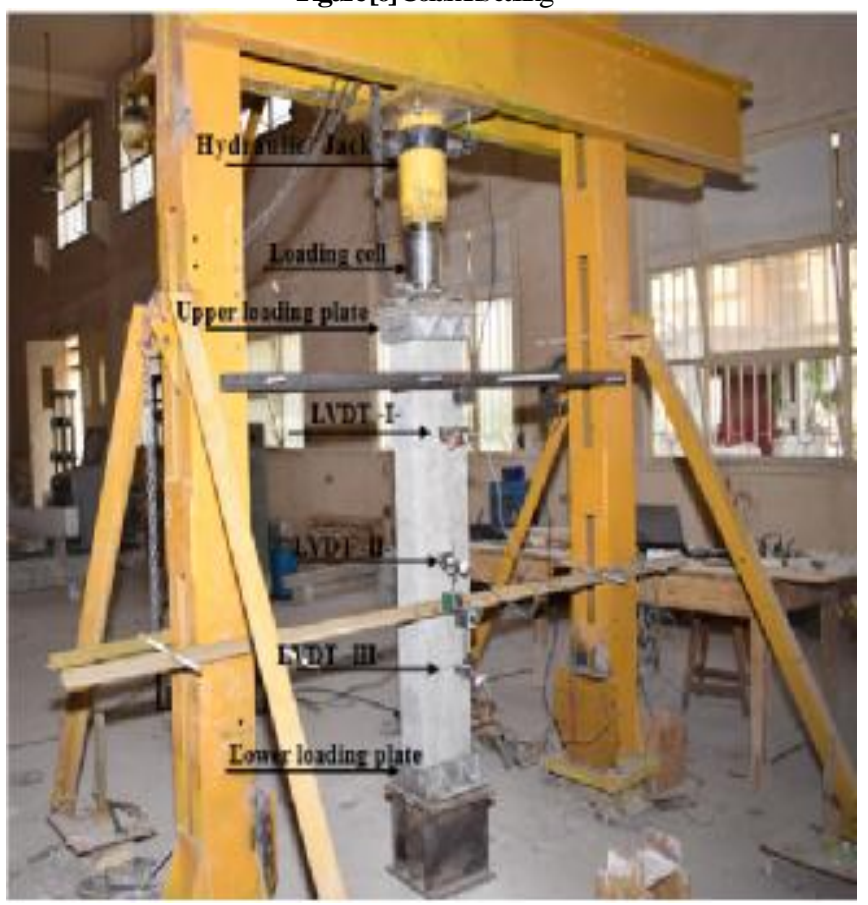

Figure [7] loading frame and test setup

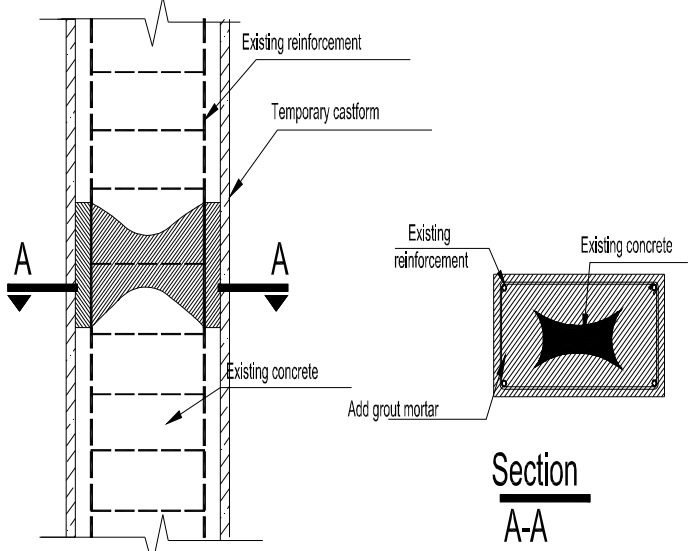

Figure [8 Localized removal and replacement of damaged concrete
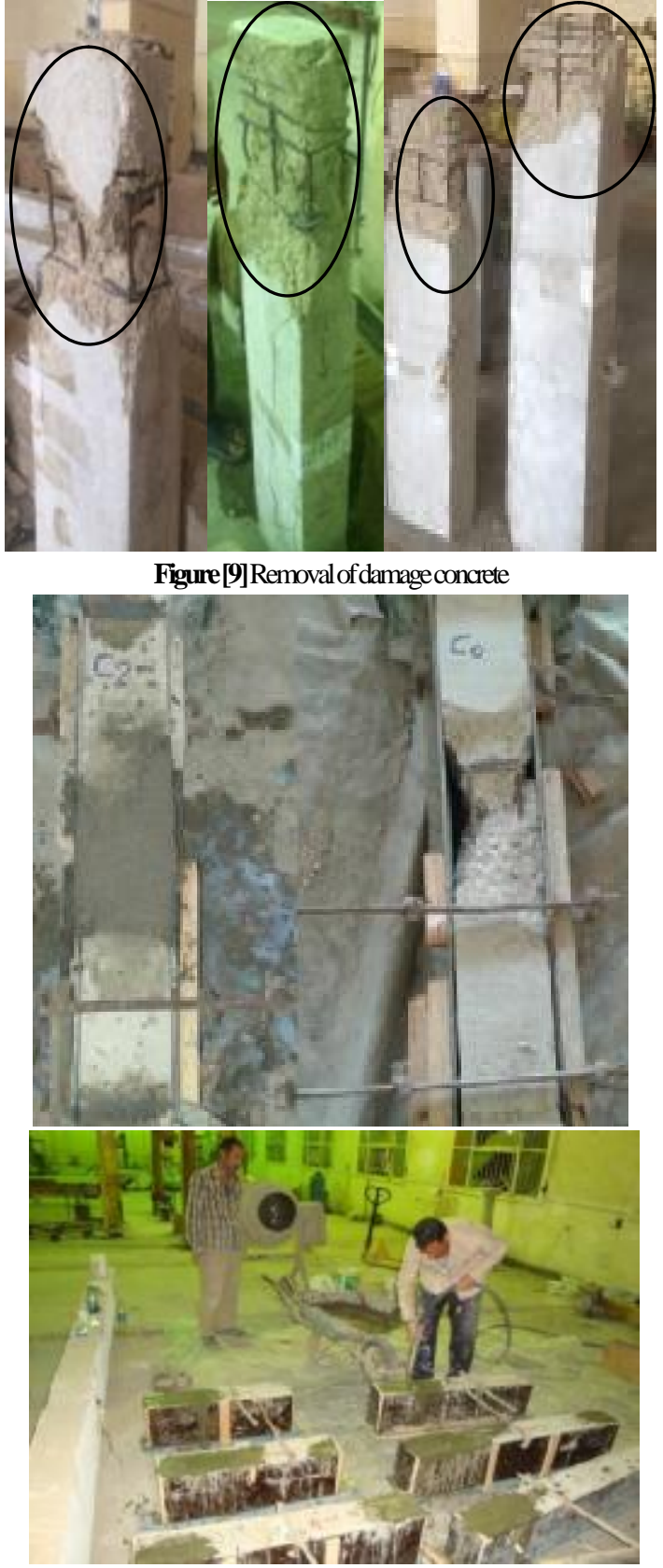

Figure [10] Replacement of damaged concrete by grout mortar

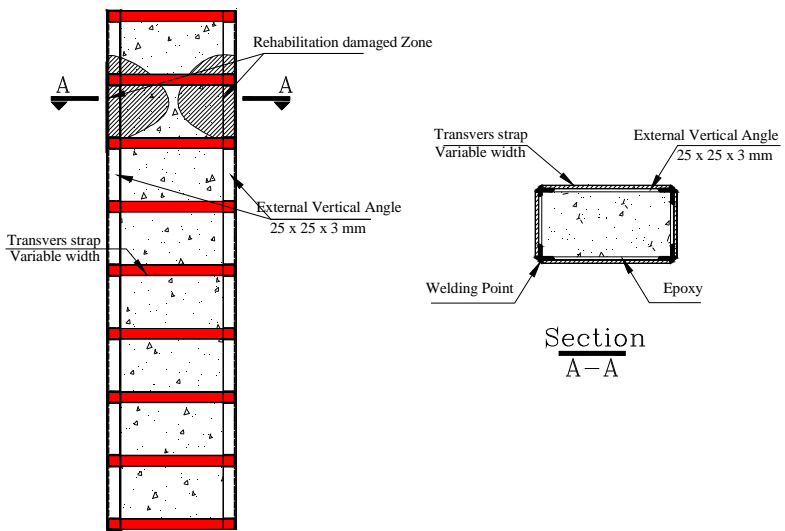

Figure[11] general rehabilitation technique fordamaged columns 


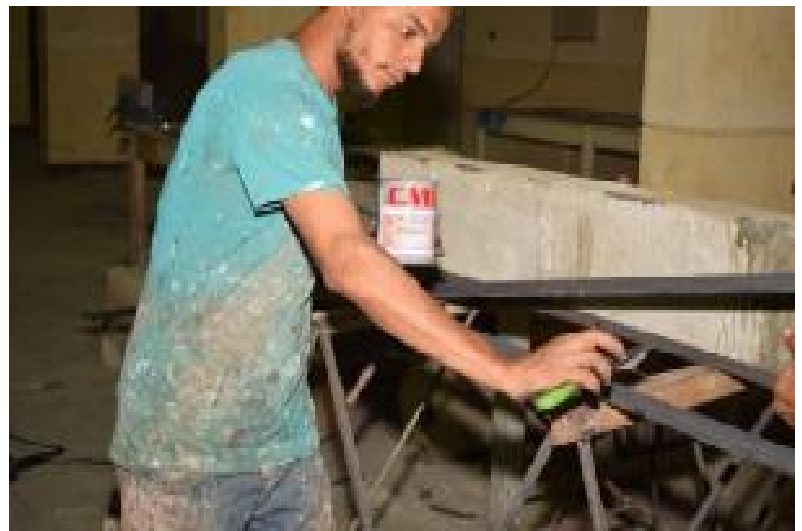

Figure [12] Using epoxy adhesive mortar to ensure full contact between angles and concrete columns

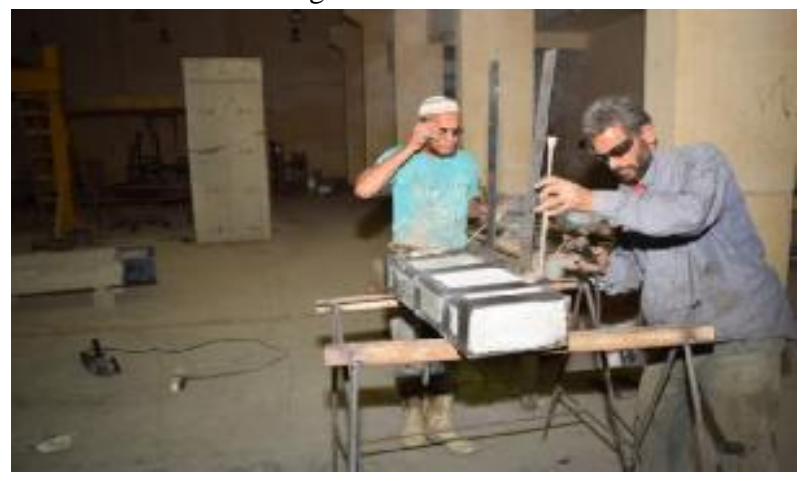

Figure[13] Waping the horizontal straps around the column and fixation of straps and anglesbywelding

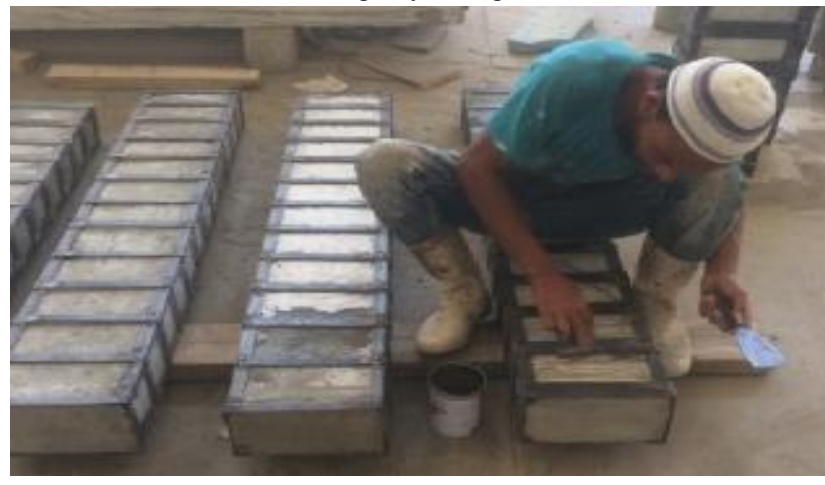

Figure [14]Applying epoxy adhesivemotartoensurefull contact between straps and concretecolumns

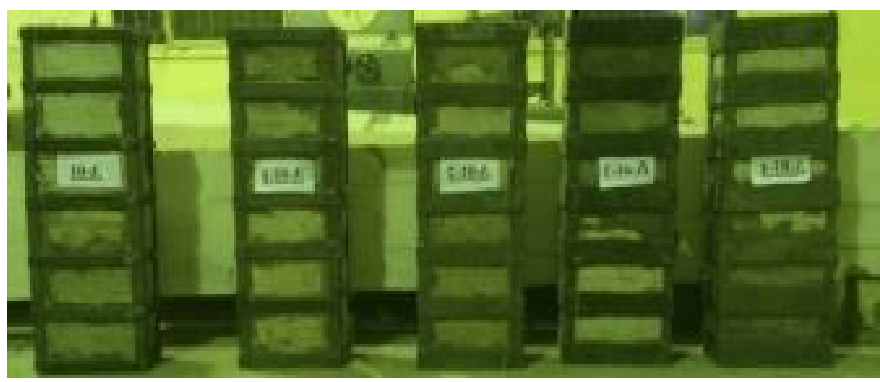

Ass $-36 \% \quad$ Ass $-42 \% \quad$ Ass $-50 \% \quad$ Ass $-57 \% \quad$ Ass $-64 \%$

Figure [15] Details of steel jacketing for general rehabilitation of columns with slendemess ratio6 for group-1R with a variable of percentage of covered steel surface areato column surface area36,42,50,57 and $64 \%$ respectively

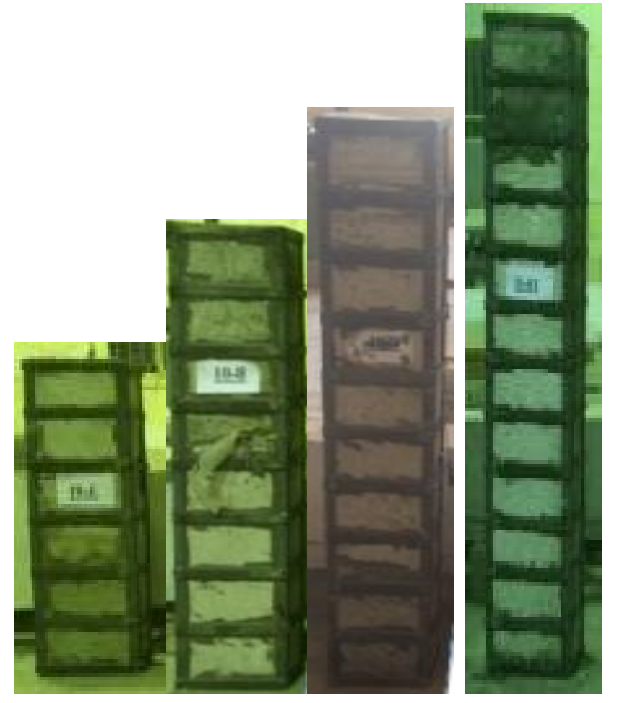

Figure [16] Details of steel jacketing for general rehabilitation by using four extemal vertical steel angles $(25 \times 25 \times 3)$ mm connected with variablenumber of hoizontal steel straps $(7,9$,

11 and13), different slendemessratio $(6,8,10$ and 12) and percentage of covered steel surface areato column surface area $36 \%$
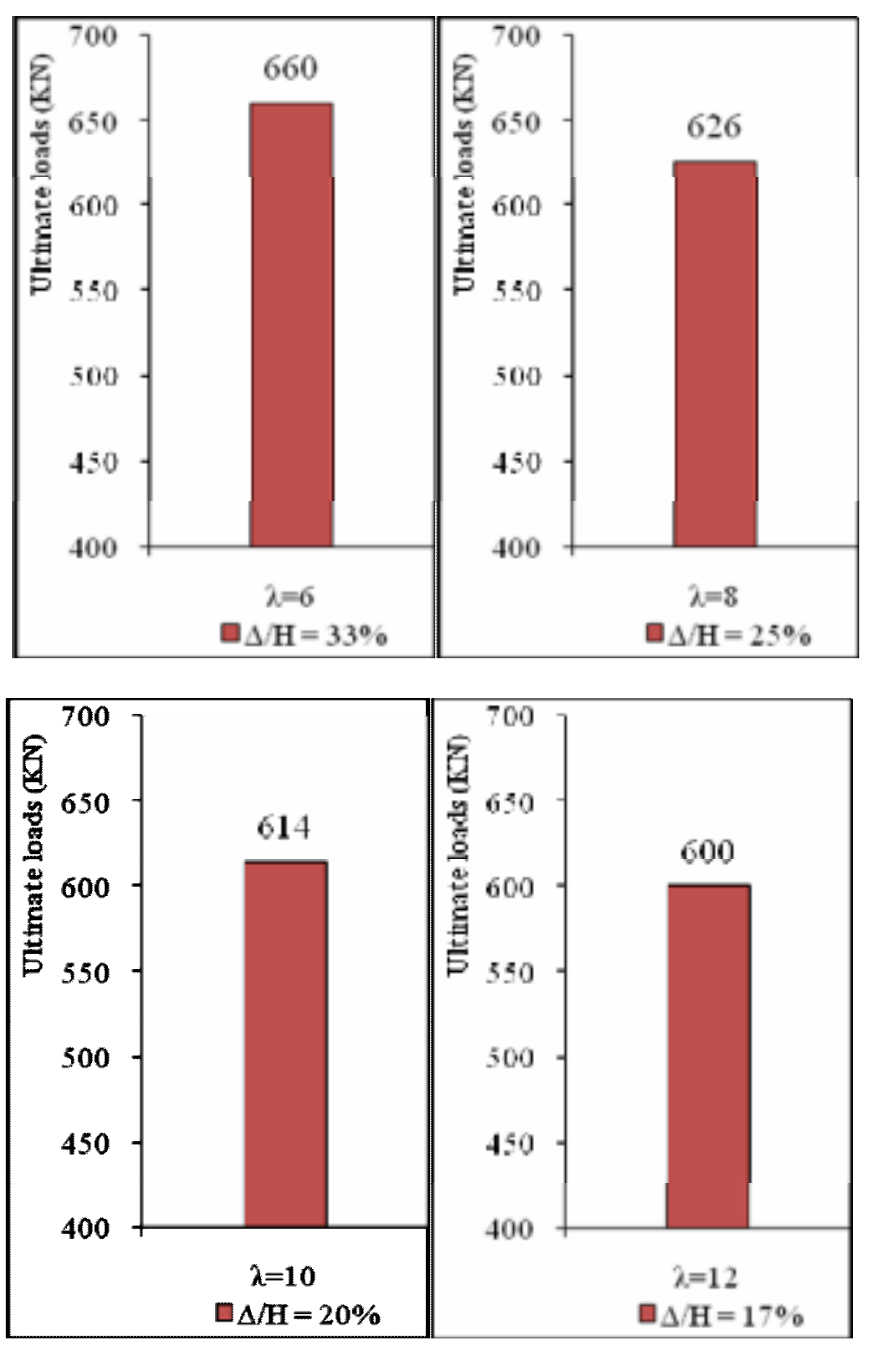

Figure [17] Relationship between slendemess ratio $(\lambda)$ and ultimate load for columns with intermal confinement by using different percentage of stimups densification $(\Delta h) 33,25,20$ and $17 \%$ and different slendemess ratio $(\lambda)$ 6,8,10and 12 respectively 


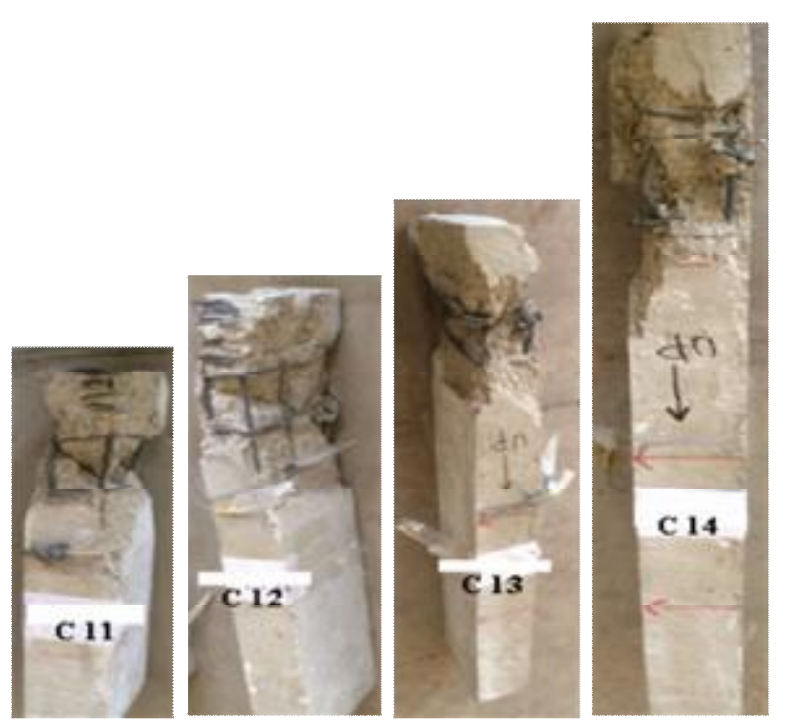

Figure[18]Failuremode of column for group-1 withintemal confinementbyusing different percentage of stimups densification $(M$ h) $33,25,20$ and $17 \%$ and different slendemessratio $(\lambda)$ 6,8,10and 12 respectively

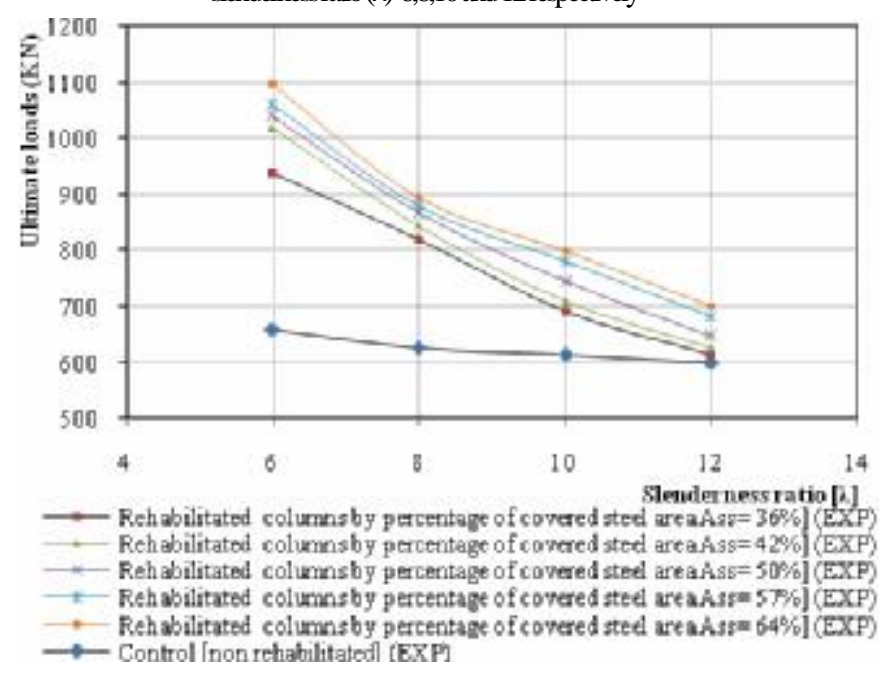

Figure [19]Relationship between slendemess ratio $(\lambda)$ and ultimate load withdifferent percentage of covered steel surface area to column surface area $\left(\mathrm{A}_{\mathrm{SS}}\right) 36,42,50,57$ and 64 $\%$ and control columns

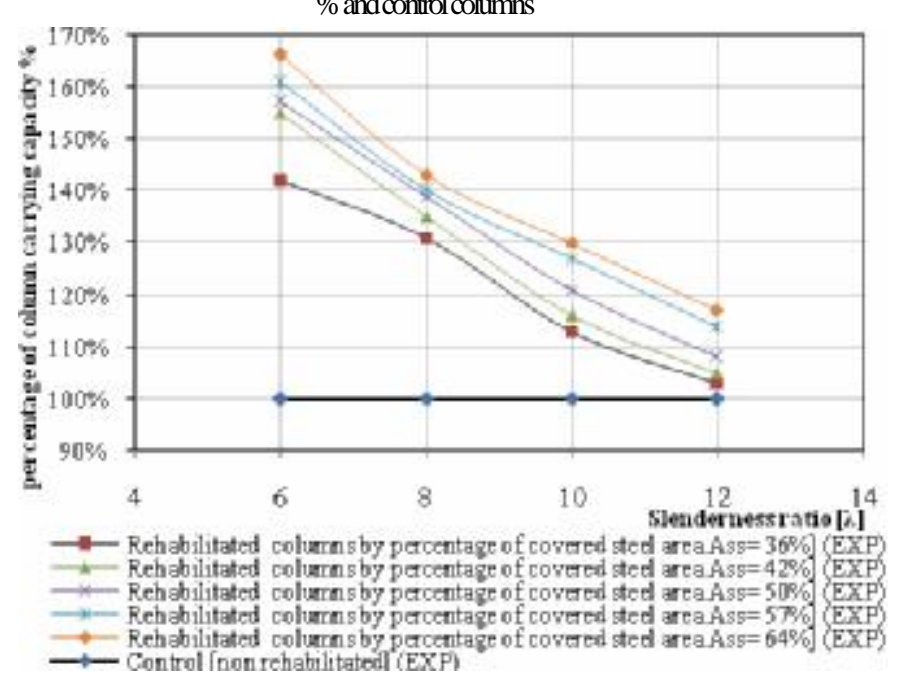

Figure [20]Relationship between slendemess ratio $(\lambda)$ and percentage of column carrying capacity with adifferent percentage of covered steel surface area to column surface area $\left(\mathrm{A}_{5 \mathrm{~s}}\right) 36,42,50,57$ and $64 \%$ and control columns

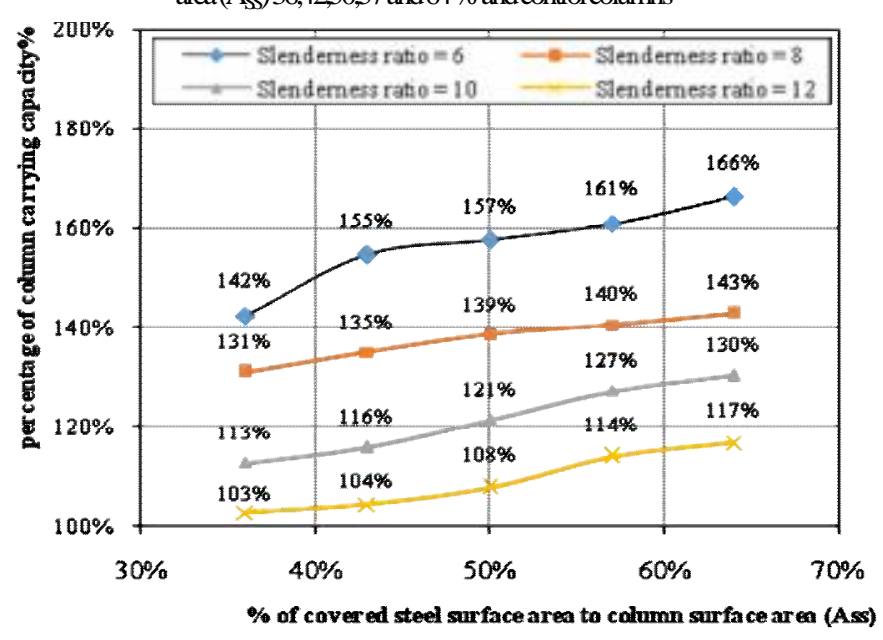

Figure [21] Relationship between percentage of columnscanying capacity and percentage of covered steel area to column surface area $\left(\mathrm{A}_{s s}\right)$ with a different slendemess ratio $(\lambda=6,8,10$ and 12$)$ forrehabilitated columns

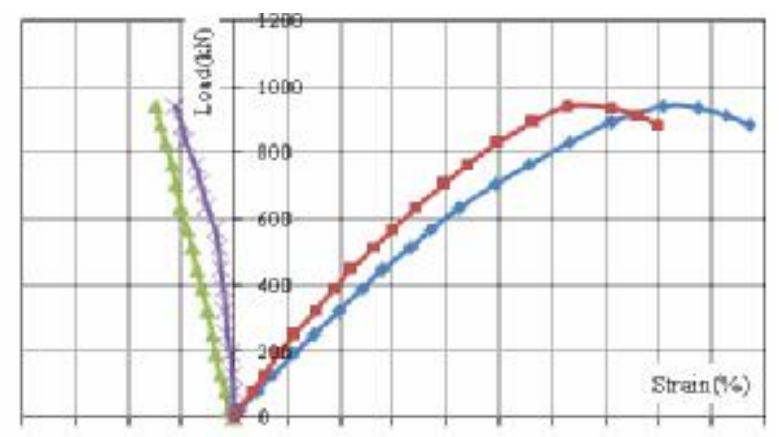

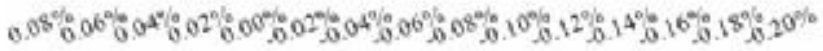

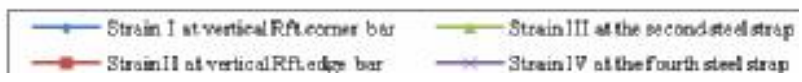

Figure [22] Relationshipbetween loads and strain at comer and middle steel bars for vertical intemal reinforcement as well as strain at second and fourth steel straps for group$1 \mathrm{R}$ with slendemess ratio $(\lambda=0$ ) and percentage of covered steel surface area to column

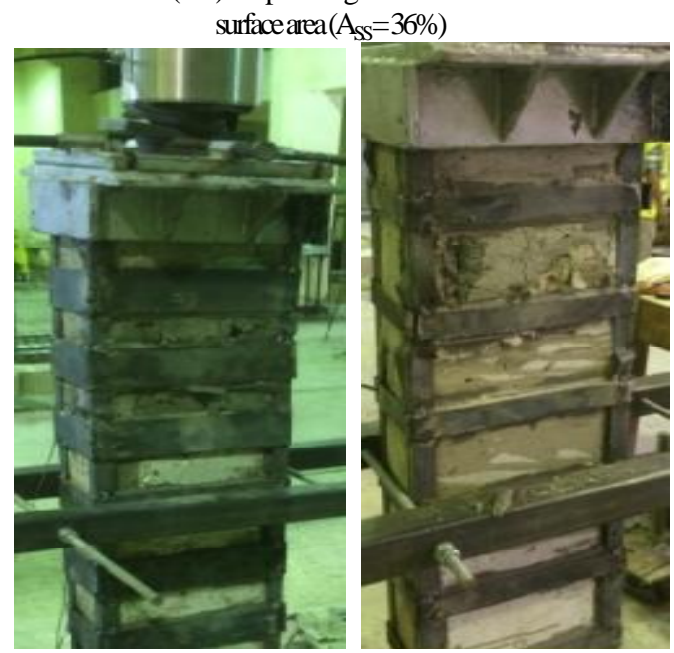

Figure[23] Failuremodes of therehabilitated columns. 


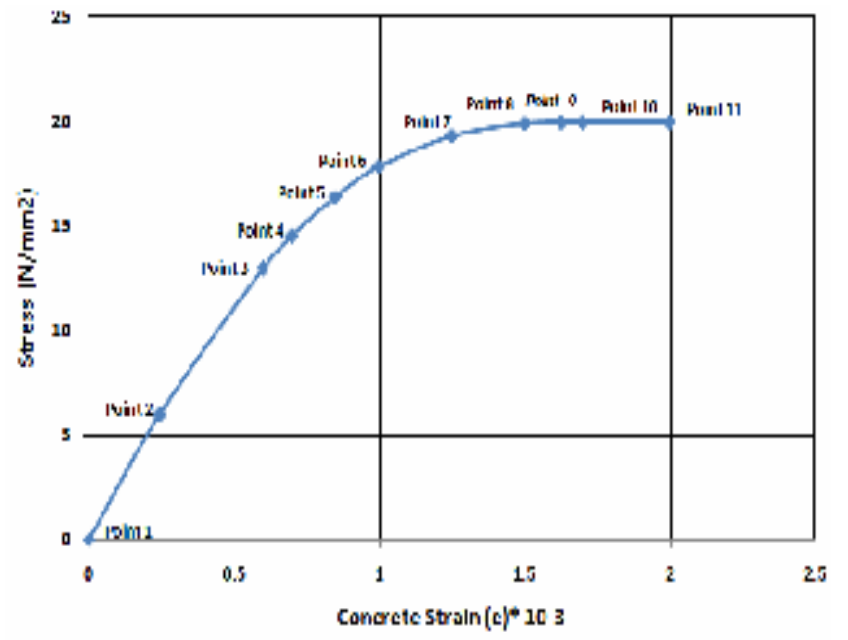

Figure[24] Concretestress straincurve $\left(\mathrm{f}_{\mathrm{a}}=20 \mathrm{MPa}\right)$

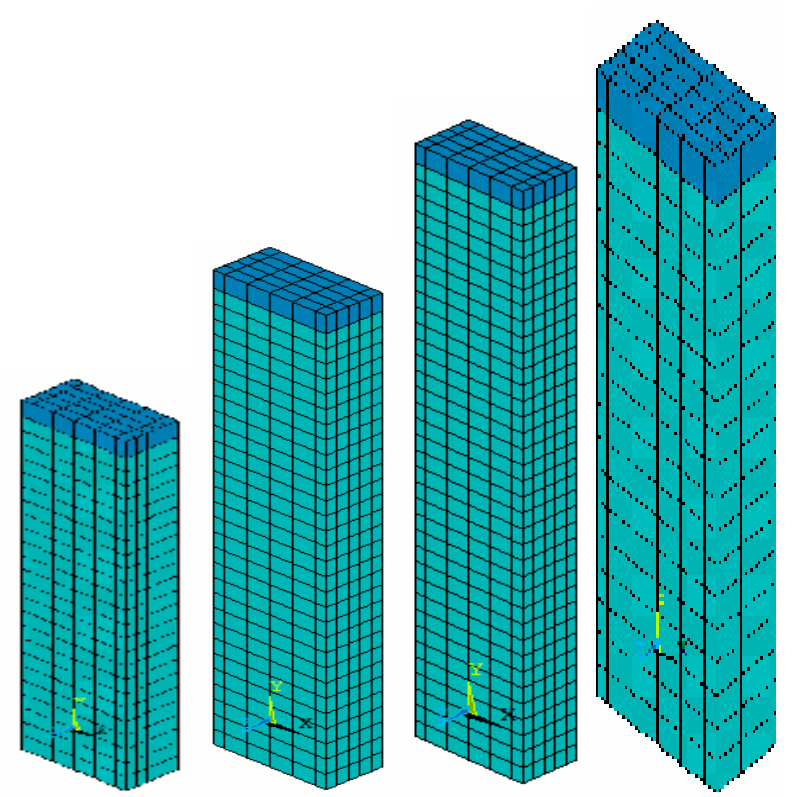

Figure [25] Modeling of concreteelements

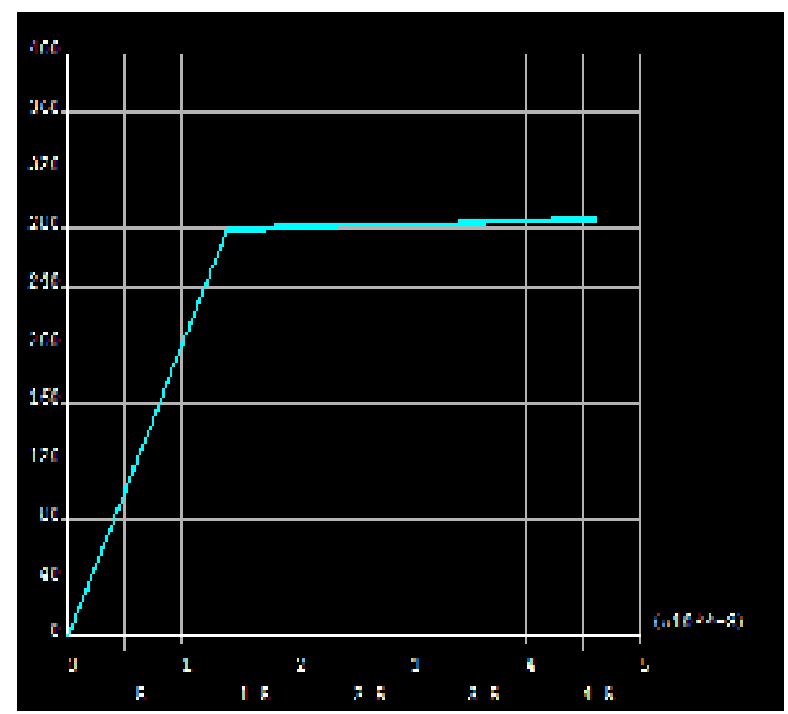

Figure[26] Idealized stress-strain forreinforcing steel bars $\left(\mathrm{f}_{\mathrm{y}}=280 \mathrm{MPa}\right)$
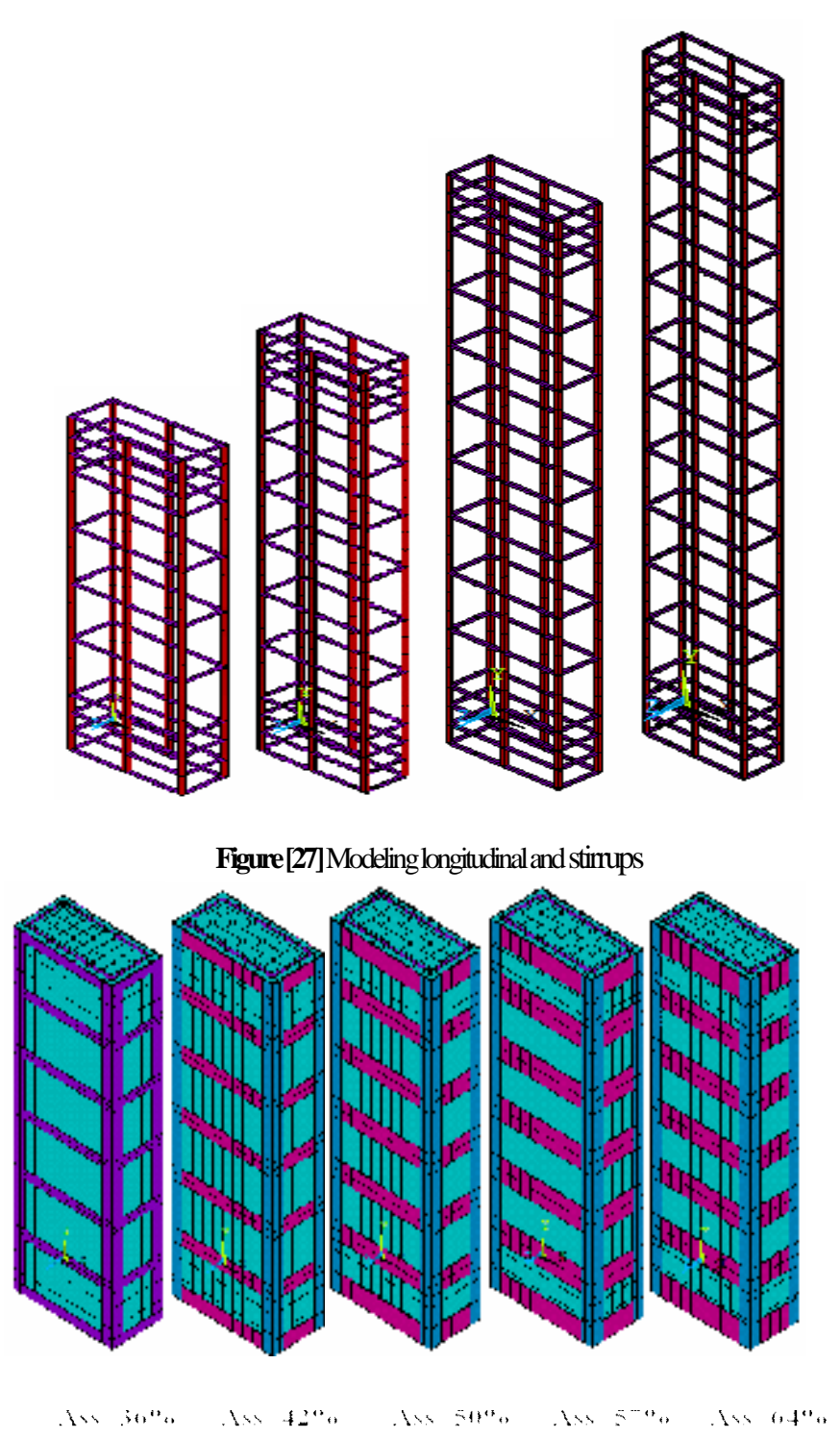

Figure[28] Modeling of steel jacketing technique

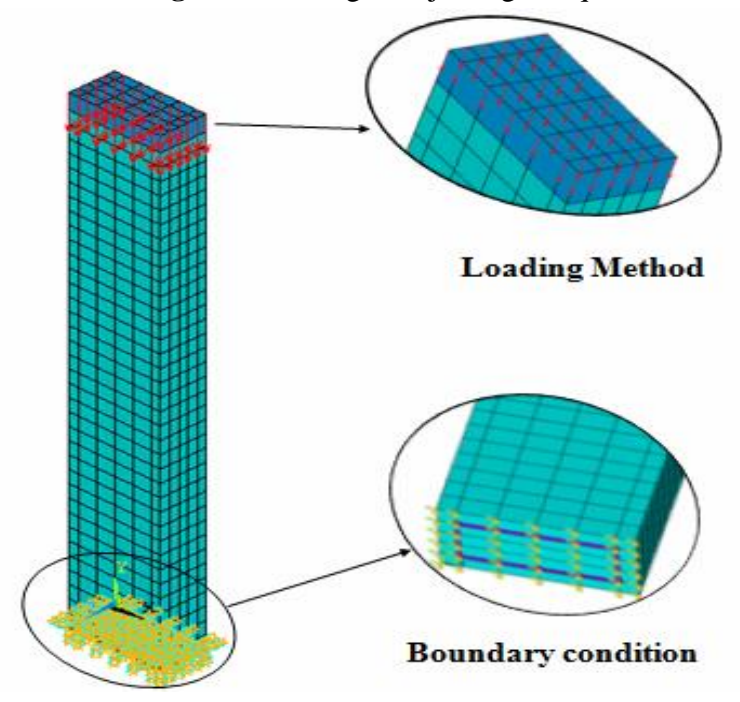

Figure[29] BoundaryconditionandLoading method of column specimen 

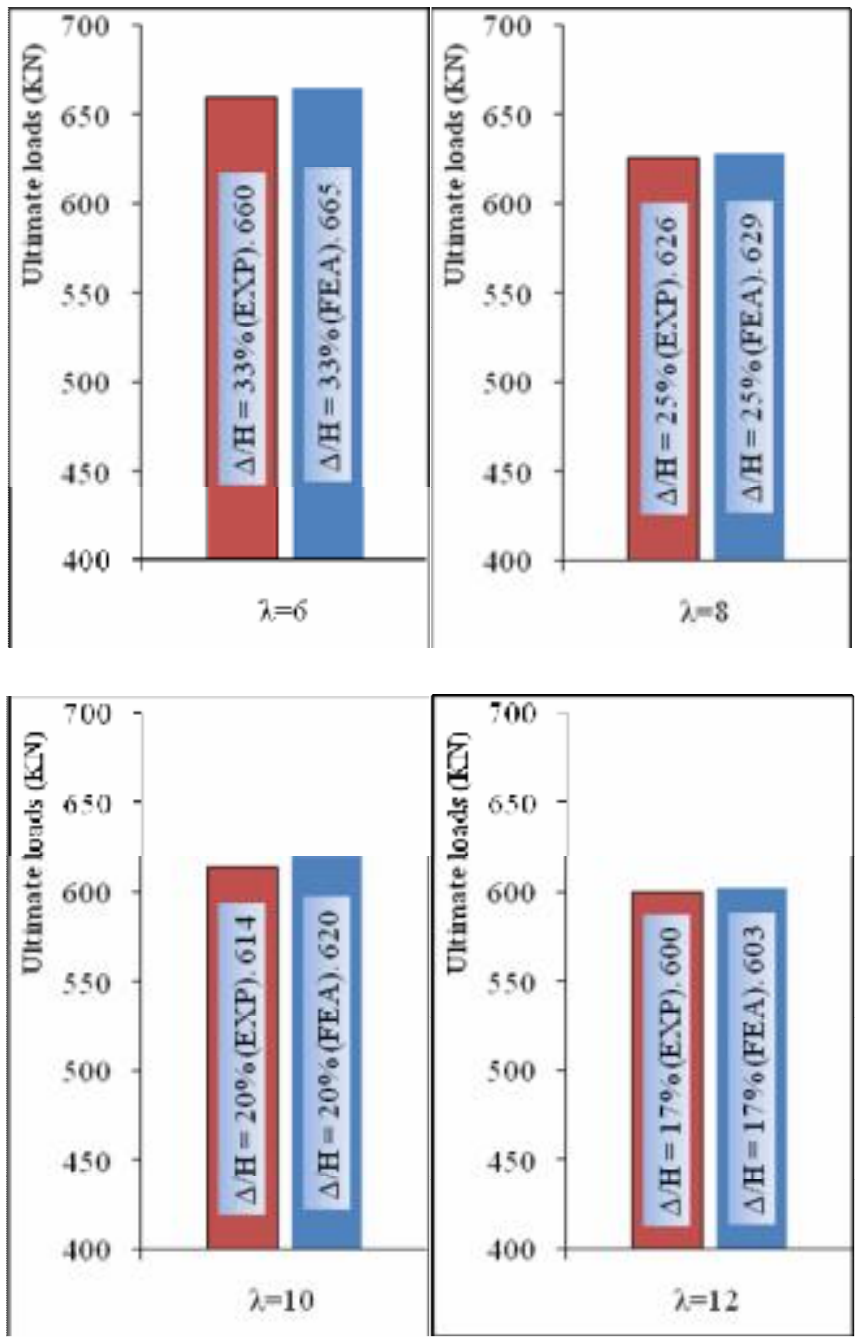

Figure [30] Companison between slendemess ratio $(\lambda)$ and ultimate load obtained firom

(FEA) and (EXP) results forcolumns withintemal confinement by using different percentage of stimups densification $(\Delta h) 33,25,20$ and $17 \%$ and different slendemessratio (入) 6,8,10and 12 respectively

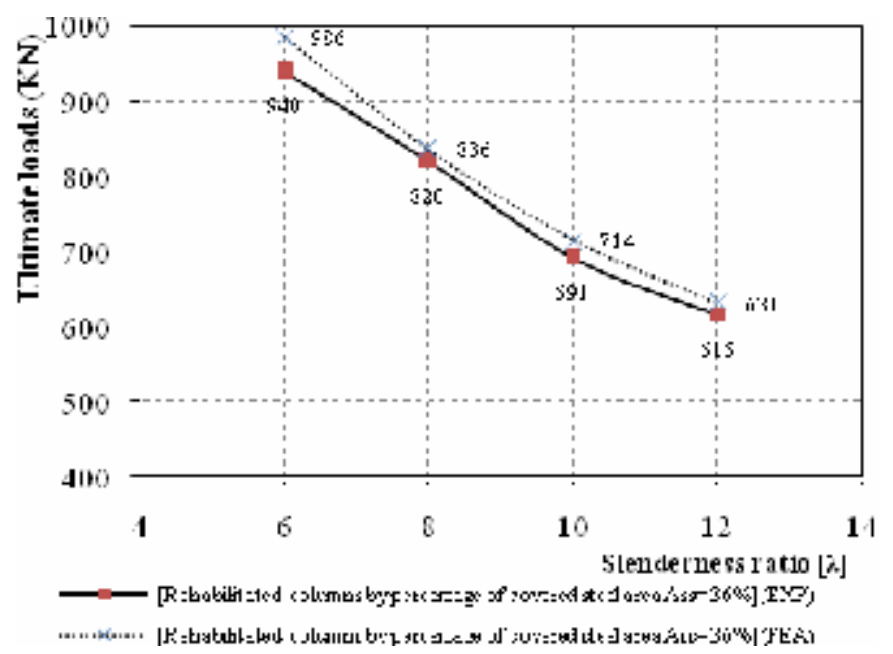

Figure[31] Companison between slendemess ratio $(\lambda)$ andultimate load obtained fiom (FEA)and(EXP) results for extemal confinement fordamaged(RC) columns group-1R with differentslendemessratio $(\lambda) 6,8,10$ and 12 and percentage of covered steel surface areatocolumn surface area $\left(\mathrm{A}_{\mathrm{sS}}\right) 36 \%$

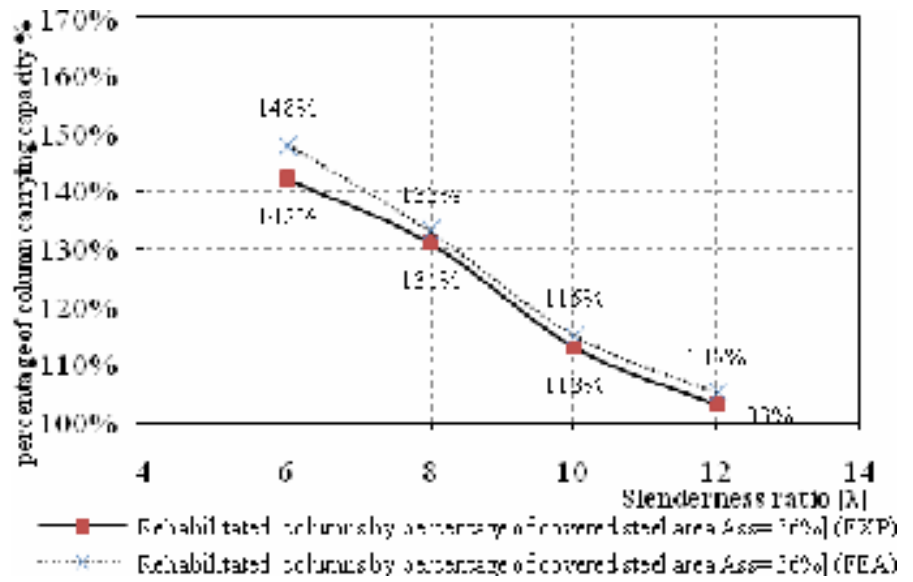

Figure [32] Comparison between slendemess ratio $(\lambda)$ and percentage of column carrying capacity obtained from(FEA) and (EXP) results extemal confinement for damaged (RC) columns with different slendemess ratio $(\lambda) 6,8,10$ and 12 and percentage of covered steel surface area to column surface area $\left(\mathrm{A}_{\mathrm{SS}}\right) 36 \%$

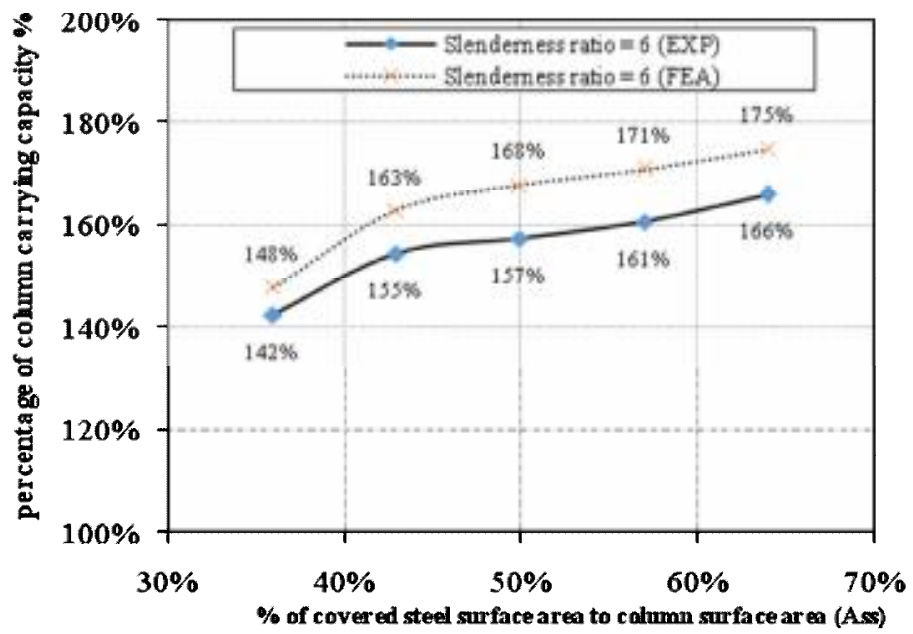

Figure [33] Comparison between percentage of columns carying capacity and percentage of covered steel areato column surface area $\left(\mathrm{A}_{\mathrm{ss}}\right)$ obtained from(FEA) and (EXP) results extemal confinement fordamaged (RC) columns
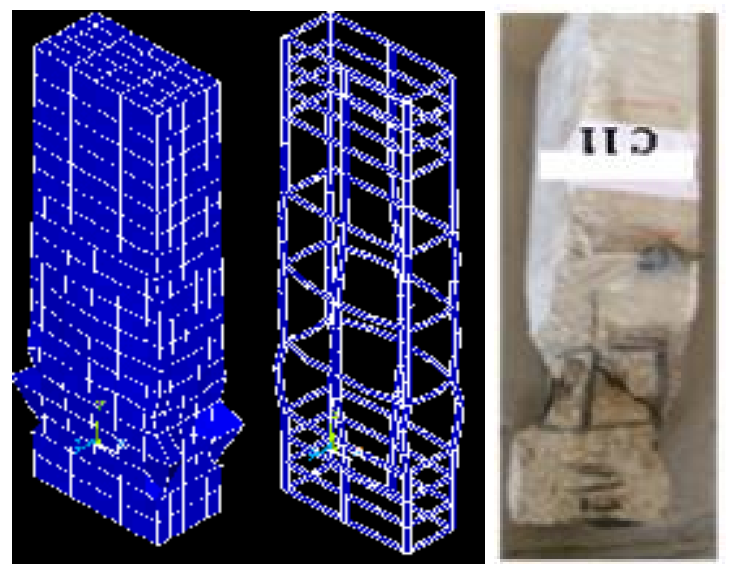

Figure [34] Comparison between modes of failureobtainedfrom(FEA) and(EXP) for columns with intemal confinement by using stimups densification at top and bottom of columns $[\mathrm{MH}] 33 \%$ 


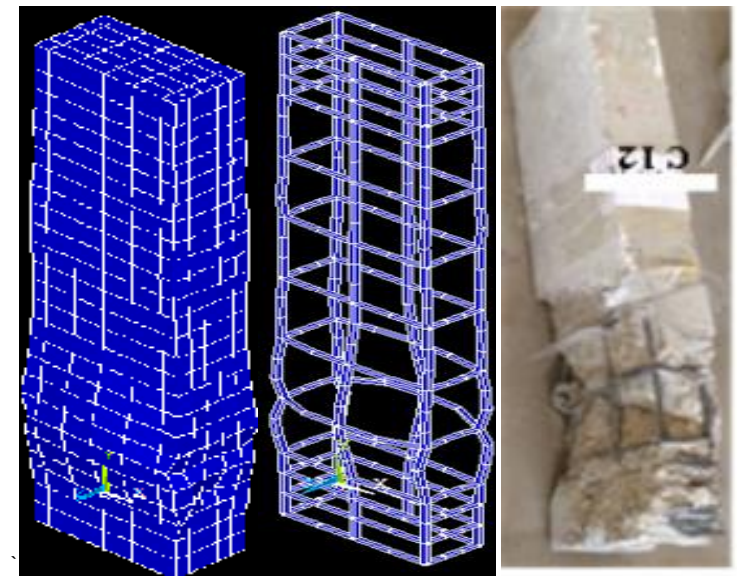

Figure[35]Comparison between modes of failureobtained from(FEA)and(EXP) for columns with intemal confinement by using stimups densification at top and bottom of

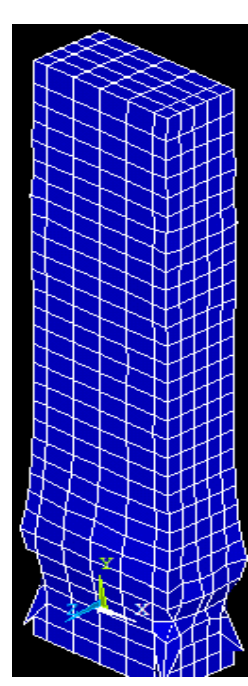
columns $[\mathrm{MH}] 25 \%$

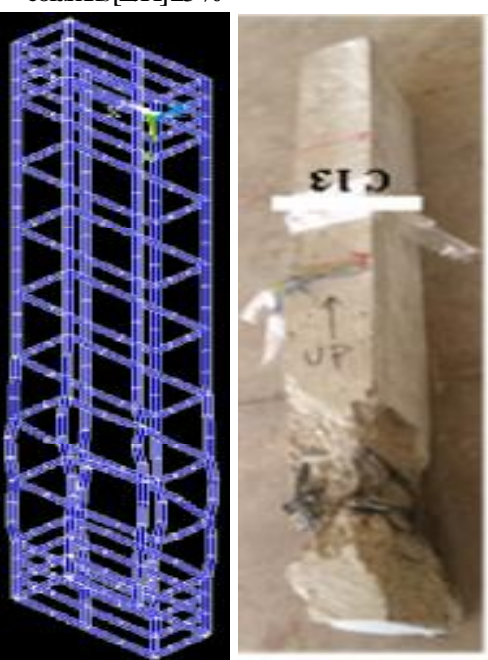

Figure [36] Companison between modes of failureobtained from(FEA) and(EXP) for columns with intemal confinementby using stimups densification at top and bottom of columns $[\mathrm{MH}] 20 \%$
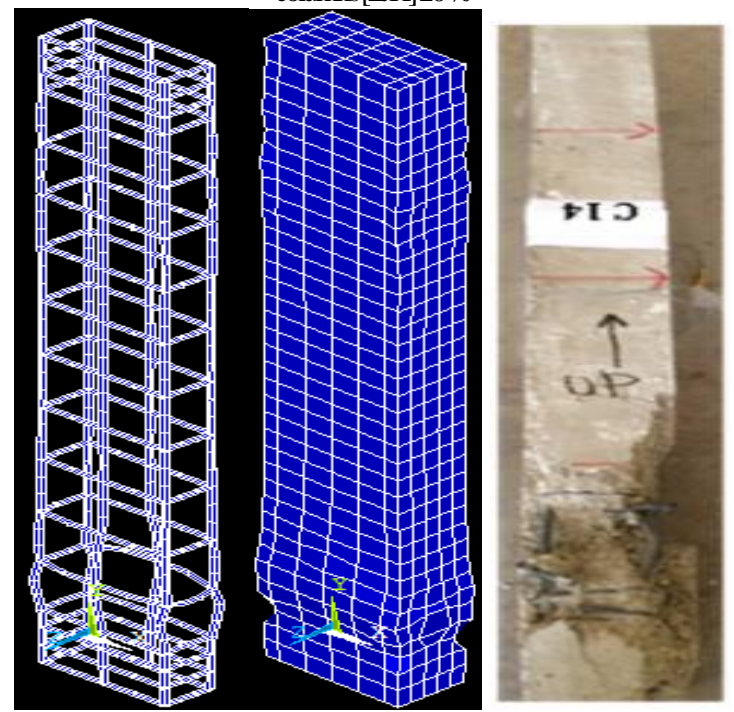

Figure [37] Comparison between modes of failureobtained from(FEA)and(EXP) for columns with intemal confinement by using stimups densification at top and bottom of columns $[\mathrm{MH}] 17 \%$

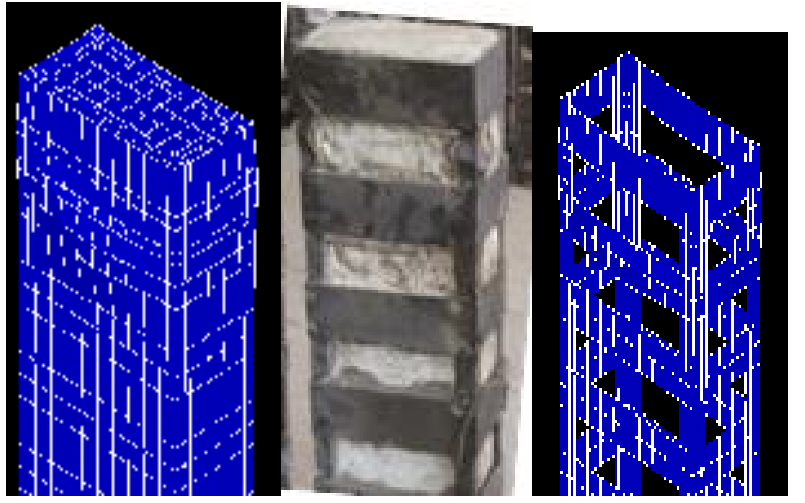

Figure [38] Comparison between modes of failure obtained from(EXP.) and(FEA) for Columnsrehabilitated by 4 angles $25 \times 3$ and straps $60 \times 3 \mathrm{~mm}$

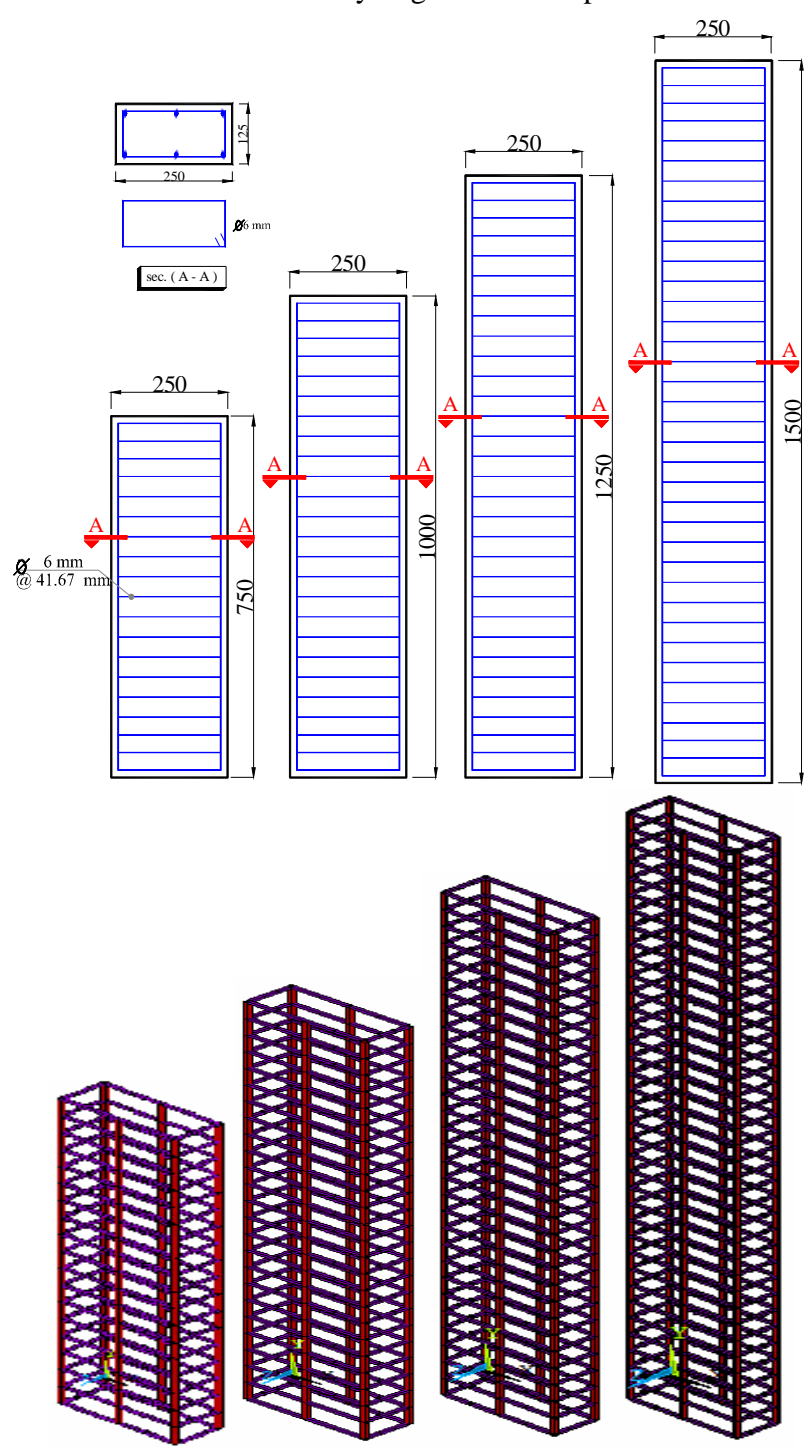

Figure [39] Details of reinforcement for group -2 with different slenderness ratio $(\lambda=6,8,10$ and 12) and regular distribution of stirrups each $41.67 \mathrm{~mm}[\mathrm{MH}] 100 \%$ 
EFFECT OF STIRRUPS DENSIFICATION AND REHABILITATION ON BEHAVIOR OF RECTANGULAR (RC) COLUMNS
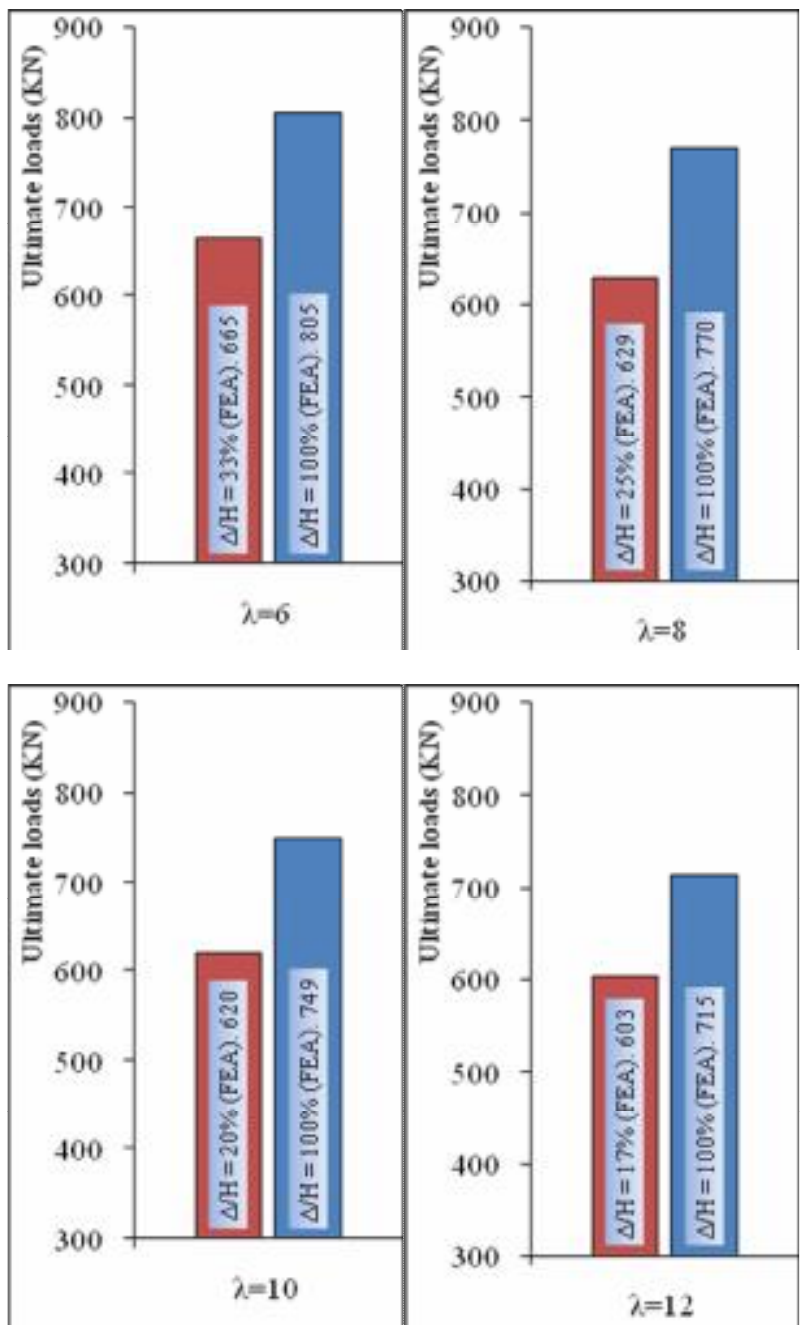

Figure [40] Comparison between slendemess ratio $(\lambda)$ and ultimate load obtained fiom(FEA)results for columns with intemal confinement by using different percentage of stimups densification at top and bottom of columns $[\mathrm{MH}] 33,25,20$ and17\% and regular simups distribution each $41.67 \mathrm{~mm}[\mathrm{MH}] 100 \%$

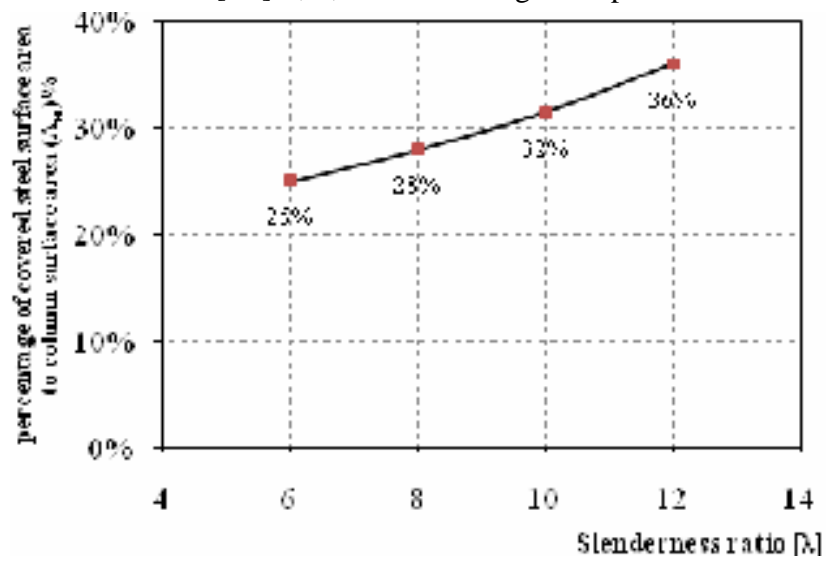

Figure [41] Relationship between slendemess ratio $(\lambda)$ and theoptimum percentage of covered steel surface areatocolumn surface area $\left(\mathrm{A}_{\mathrm{s}}\right)$ for rehabilitated columns 